\title{
Ecosystem Structure and Dynamics in the North Pacific Subtropical Gyre: New Views of an Old Ocean
}

\author{
David M. Karl ${ }^{1,2 *}$ and Matthew J. Church ${ }^{1,2,3}$
}

\begin{abstract}
${ }^{1}$ Center for Microbial Oceanography: Research and Education, C-MORE Hale, University of Hawaii at Manoa, 1950 East-West Rd., Honolulu, Hawaii 96822, USA; ${ }^{2}$ School of Ocean and Earth Science and Technology, University of Hawaii at Manoa, Honolulu, Hawaii 96822, USA; ${ }^{3}$ Present address: Flathead Lake Biological Station, University of Montana, Polson, MT 59860, USA
\end{abstract}

\begin{abstract}
The North Pacific Subtropical Gyre (NPSG) is one of the largest biomes on Earth. It has a semi-enclosed surface area of about $2 \times 10^{7} \mathrm{~km}^{2}$ and mean depth of nearly $5 \mathrm{~km}$ and includes a broad range of habitats from warm, light-saturated, nutrient-starved surface waters to the cold, nutrient-rich abyss. Microorganisms are found throughout the water column and are vertically stratified by their genetically determined metabolic capabilities that establish physiological tolerances to temperature, light, pressure, as well as organic and inorganic growth substrates. Despite the global significance of the NPSG for energy and matter transformations and its role in the oceanic carbon cycle, it is grossly undersampled and not well characterized with respect to ecosystem structure and dynamics. Since October 1988, interdisciplinary teams of scientists from the University of Hawaii and around the world have been investigating the NPSG ecosystem at Station ALOHA (A Long-term Oligotrophic Habitat Assessment), a site chosen to be representative of this expansive oligotrophic habitat, with a focus on microbial processes and biogeochemistry. At the start of this comprehensive field study, the NPSG was thought to be a "Climax"
\end{abstract}

Received 27 July 2016; accepted 6 January 2017; published online 10 March 2017

Data related to this manuscript can be found at hanaha. soest.hawaii.edu (HOT), scope.soest.hawaii.edu (SCOPE), cmore.soest.hawaii.edu (CMORE).

Authors' contributions DMK conceived the study. DMK and MJC performed research, analyzed data and contributed new methods. DMK and MJC wrote the paper.

*Corresponding author; e-mail: dkarl@hawaii.edu community with a relatively stable plankton community structure and relatively low variability in key microbiological rates and processes. Now, after nearly three decades of observations and experimentation we present a new view of this old ocean, one that highlights temporal variability in ecosystem processes across a broad range of scales from diel to decadal and beyond. Our revised paradigm is built on the strength of high-quality time-series observations, on insights from the application of state-of-the-art -omics techniques (genomics, transcriptomics, proteomics and metabolomics) and, more recently, the discoveries of novel microorganisms and metabolic processes. Collectively, these efforts have led to a new understanding of trophic dynamics and population interactions in the NPSG. A comprehensive understanding of the environmental controls on microbial rates and processes, from genomes to biomes, will be required to inform the scientific community and the public at large about the potential impacts of humaninduced climate change. The pace of new discovery, and the importance of integrating this new knowledge into conceptual paradigms and predictive models, is an enormous contemporary challenge with great scientific and societal relevance.

Key words: microbial oceanography; North Pacific Subtropical Gyre; biogeochemistry; primary production; oceanic carbon cycle; climate change; time series. 


\section{INTRODUCTION}

In 1999, one of us (Karl 1999) published a "mini review" in volume \#2 of Ecosystems that summarized the state of knowledge on microbial and biogeochemical variability in the North Pacific Subtropical Gyre (NPSG). At that time, the Hawaii Ocean Time-series (HOT) program had already amassed one of the most comprehensive data sets for any open ocean ecosystem ( 10 years of approximately monthly observations) and was beginning to erode the "chronic undersampling" barrier that existed at that time. Because previous zonal and meridional transects across the NPSG had documented weak horizontal gradients in many physical, chemical and biological characteristics, relative to other regions of the ocean (Venrick 1971; Hayward and McGowan 1985), serial observations at a strategically located sampling site might be scaled up to the larger region of interest (Karl 1999). This basic premise underlies the establishment of Station ALOHA (A Long-term Oligotrophic Habitat Assessment) at $22^{\circ} \mathrm{N} 45^{\prime} \mathrm{N}, 158^{\circ} \mathrm{W}$ (Figure 1A) as a NPSG benchmark (Karl and Winn 1991; Karl and Lukas 1996). The HOT program was designed to extend the knowledge base that was gained during the extensive study of the climax region at $28^{\circ} \mathrm{N}, 155^{\circ} \mathrm{W}$ (Hayward and others 1983), during which time the NPSG exhibited a doubling in the concentrations of chlorophyll $a$ and rates of primary production (Venrick and others 1987; Karl and others 2001a; Figure 1B, C). The establishment of Station ALOHA would also provide an opportunity to test novel methods and instrumentation and to serve as a natural laboratory for hypothesis testing, experimentation and ocean science education and training. These data sets would eventually be used to develop a predictive capability for global environmental change, by elucidating the pathways and controls on physical and biological processes that govern the fluxes of carbon (C) into and from the ocean, especially the key roles of microorganisms (Figure 2).

The immediate successes of the HOT program also brought attention to the poor state of knowledge about the sea around us and catalyzed the establishment of similar programs at strategic coastal and open ocean locations worldwide. In 2006, a US National Science Foundation Center of Excellence in Microbial Oceanography was established at the University of Hawaii in collaboration with six partner institutions. The Center for Microbial Oceanography: Research and Education (C-MORE) was literally built on a "HOT foundation." The colocation of these two major field programs served to consolidate the importance of Station ALOHA as a site to advance the discipline of microbial oceanography. Between 2006 and 2016, C-MORE scientists made numerous discoveries of novel microorganisms, metabolic pathways and population interactions. They also facilitated an understanding of the time-space continuum by conducting higher-frequency temporal sampling (hourly to weekly) than was possible to achieve in the HOT program structure and expanded regional analyses using ships and remotely operated vehicles to better understand mesoscale variability (10$100 \mathrm{~km}$ ) in microbial dynamics in the NPSG. In 2014, a second complementary field-based research program was established at Station ALOHA. The Simons Collaboration on Ocean Processes and Ecology (SCOPE) is an international research program with a mission to characterize the flows of energy and matter through NPSG microbial assemblages and into the mesopelagic zone. The primary stated goal for this planned, decade-long program is to quantify the inputs to, and outputs from, the upper ocean $(0-200 \mathrm{~m})$ at Station ALOHA and to incorporate this new knowledge into ocean models. In November 2015, the American Society for Microbiology designated Ocean Station ALOHA as a "milestones in microbiology" site in recognition of historic and visionary accomplishments.

This review will focus on four complementary themes: (1) the fundamental role of sunlight in the structure and function of the NPSG, (2) phytoplankton diversity, (3) controls on primary production and carbon export and (4) habitat variability, including the time-space continuum and potential impacts of human-induced climate change. The review concludes with some thoughts on future challenges and opportunities.

\section{Station AlOHA: A Proving Ground For Microbial OCEANOGRAPHy}

Research at Station ALOHA has had a major impact on how we study, interpret and model microbial processes in oligotrophic ecosystems. Many of the general characteristics of the NPSG habitat were known prior to the establishment of Station ALOHA (Karl and Lukas 1996), but other key features were either poorly understood or not yet discovered. For example, the three major groups of microorganisms that are numerically dominant members of the NPSG ecosystem (that is, Prochlorococcus spp., the SAR1l clade of Alphaproteobacteria and planktonic archaea) were all dis- 

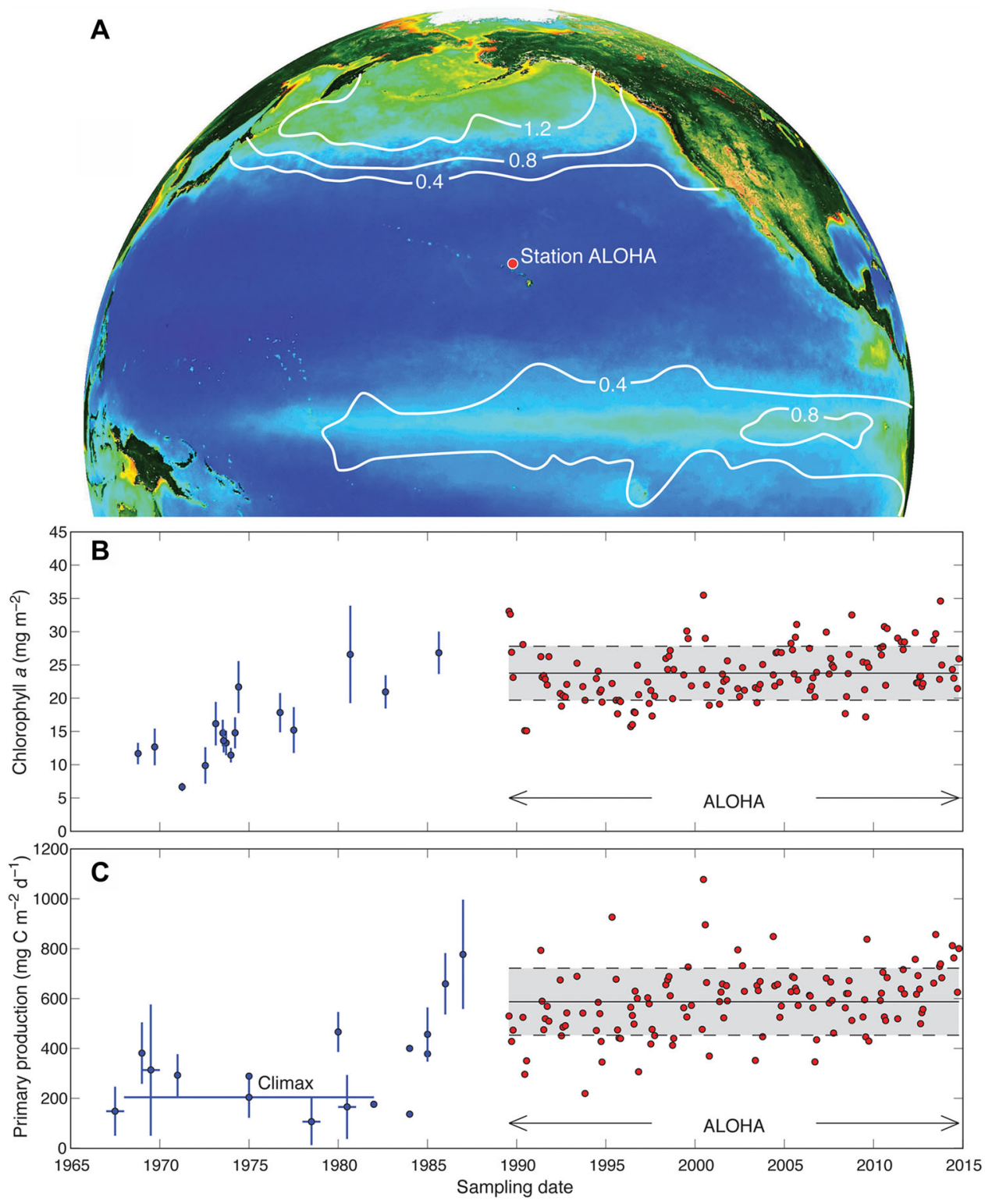

Figure 1. (A) Map of the North Pacific Ocean showing the location of Station ALOHA $\left(22^{\circ} 45^{\prime} \mathrm{N}, 158^{\circ} \mathrm{W}\right)$ within the NPSG. The background colors depict summer chlorophyll $a$ distributions as determined by the SeaWiFS satellite mission (oceancolor.gsfc.nasa.gov/SeaWiFS/) with blue regions corresponding to the lowest concentrations $\left(<0.1 \mathrm{mg} \mathrm{m}^{-3}\right)$ and green-yellow-red corresponding to higher concentrations $\left(>1 \mathrm{mg} \mathrm{m}^{-3}\right)$. The white contours represent mean annual surface ocean phosphate concentrations $\left(\mu \mathrm{mol} \mathrm{l}^{-1}\right)$ and emphasize the correspondence between chlorophyll $a$ and nutrient concentrations. (B) Euphotic zone depth-integrated chlorophyll $a$ as determined by the standard fluorometric method. The solid and dashed lines for the Station ALOHA-era data set represent the mean \pm 1 SD (mean $=23.76$, $\mathrm{SD}=4.05, n=131)$. (C) Euphotic zone depth-integrated rates of primary production as determined by the standard ${ }^{14} \mathrm{C}$ method. Most of the data prior to the Station ALOHA-era were collected at or near the Climax study region and, where appropriate, represent the mean \pm 1 SD for multiple observations for a given cruise, season or study. Horizontal bars indicate the duration of multicruise data sets ("C" indicates Climax program; see Karl and others 200la). The solid and dashed lines for the Station ALOHA-era data set represent the mean \pm 1 SD (mean $=577.4, \mathrm{SD}=129.1, n=127$ ).

covered after the establishment of Station ALOHA in 1988 (Karl and Church 2014). Although marine viruses were discovered in the late 1970s (Torrella and Morita 1979), it was not until a decade later that quantitative estimates were available (Bergh and others 1989). Furthermore, the origins of the marine -omics revolution post-date the establishment of Station ALOHA, for example, the first 

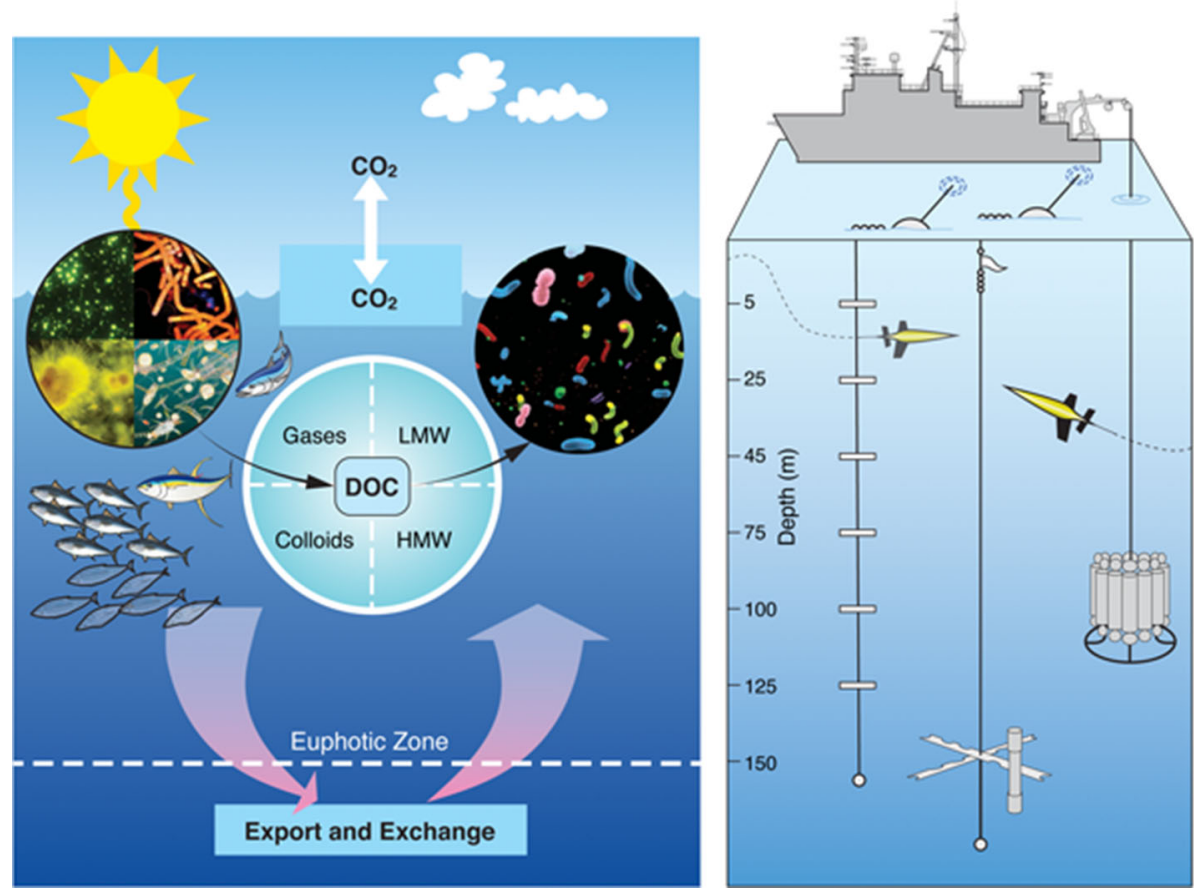

Figure 2. Carbon cycle processes at Station ALOHA. (Left) Schematic representation of key euphotic zone variables including primary production, microbial loop processes and net export of carbon and energy to the mesopelagic zone below. DOC is dissolved organic carbon. (Right) Schematic representation of several modes of sampling and experimentation including (from left) in situ primary production array, sediment traps positioned near the base of the euphotic zone and CTD-rosette water sampler. Autonomous Seagliders are deployed for data collection when the surface ship is not on site.

bacterial genome sequence (Fleishmann and others 1995), the Sargasso Sea metagenome (Venter and others 2004) and the first marine metatranscriptome (Frias-Lopez and others 2008).

Open ocean ecosystems like those represented by Station ALOHA are characterized by warm surface waters $\left(>24^{\circ} \mathrm{C}\right)$ throughout the year that establishes a permanent low-density cap, isolating the upper layer $(\sim 0-100 \mathrm{~m})$ from the water column below (Figure 3). This stratified upper zone has excess solar energy, but is chronically depleted in inorganic nutrients (Karl and Church 2014). In contrast, deeper waters $(>100 \mathrm{~m})$ have limited or no solar energy, but high concentrations of inorganic nutrients. This observed physical separation between excess light in surface waters and excess nutrients at depth leads to a condition of extreme oligotrophy with low concentrations of chlorophyll a $\left(<100 \mu \mathrm{g} \mathrm{m}^{-3}\right)$, low biomasses of microorganisms and relatively high proportions of organic detritus (that is, dissolved and non-living particulate organic matter). Detailed descriptions of the seasonally resolved habitat characteristics have been summarized elsewhere (Karl 1999; Karl and others 1996, 2001a, b, 2008; Church and others
2013; Karl 2014a; Karl and Church 2014) and will not be repeated here, other than to emphasize the fundamental role of sunlight in structuring communities and ultimately controlling most microbiological rates and processes (see below). The complete Station ALOHA data set is publicly available at http://hahana.soest.hawaii.edu/hot/ hot_jgofs.html along with a listing of more than 650 scientific papers reporting field observations, methods development and applications, and physical-biogeochemical model simulations of ecosystem processes.

\section{Light: The "STAFF OF LifE"}

Simply stated, light is life. With the possible exception of exotic, deep subsurface habitats that are ultimately supported by energy supplied via the decay of radioactive elements (for example, Lin and others 2006; Chivian and others 2008), most ecosystems on Earth, all biogeochemical cycles and all evolutionary processes are ultimately solar powered. Consequently, a comprehensive understanding of ecosystem structure and function must include a detailed analysis of rates and controls on 


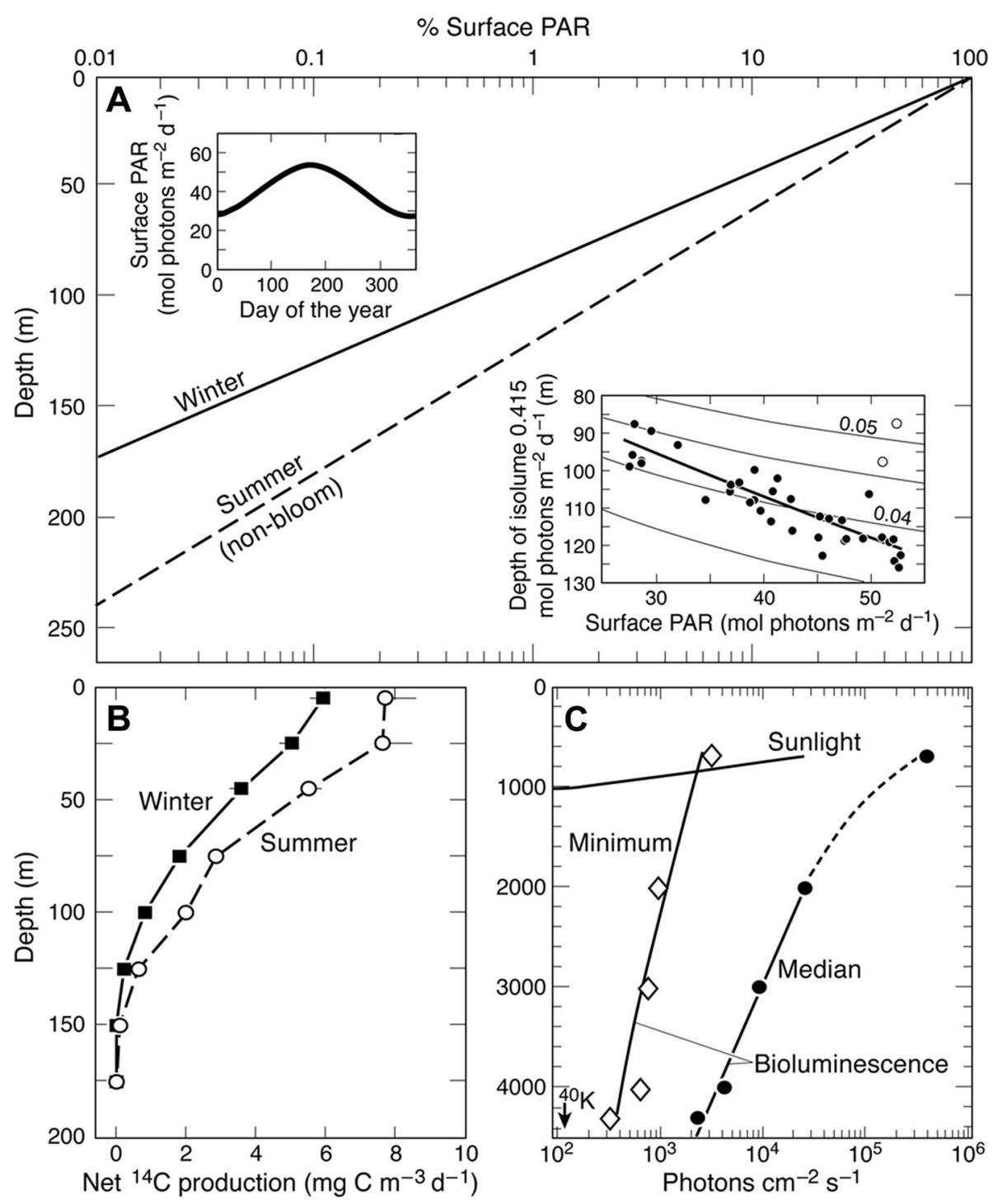

Figure 3. Various light fluxes at Station ALOHA. (A) Photosynthetically available radiation (PAR) versus depth displayed as percent surface PAR for winter and non-bloom summer conditions. Inset on left shows annual variation in surface PAR. Inset on right shows variation in the depth $(\mathrm{m})$ of the $0.415 \mathrm{~mol}$ photons $\mathrm{m}^{-2} \mathrm{~d}^{-1}$ isolume as a function of surface PAR (season). The two open symbols on the right, well above the trend line, are from summer blooms. Redrawn from Letelier and others (2004). (B) Winter and summer mean daily rates of ${ }^{14} \mathrm{C}$-based primary production as determined by difference uptake in the light and in the dark at Station ALOHA. (C) Meso- and abyssopelagic light fluxes showing sunlight, bioluminescence and the estimated "glow" from radioactive potassium $\left({ }^{40} \mathrm{~K}\right)$ dissolved in seawater. The bioluminescence data are presented as minimum (background) and median intensity of light flashes detected using a calibrated 5-inch EMI photomultiplier with a 0.1-s time constant. Redrawn from Bradner and others (1987).

solar energy capture and transformation (Karl $2014 \mathrm{~b}$ ). In the NPSG, the major portion of solar energy is harvested by phytoplankton via "green plant-like photosynthesis" termed oxygenic phototrophy (OP). Light-driven oxidation of water provides electrons and hydrogen ions that partially conserve the solar energy absorbed by chlorophyll $a$ to catalyze the production of a variety of reduced inorganic and organic molecules and produce free oxygen $\left(\mathrm{O}_{2}\right)$. Both the inherent optical properties of light in the ocean (absorption and scattering) and the pathways of solar energy capture during OP are well known (Falkowski and Raven 2007; Kirk 2011). However, new aspects of microbial phototrophy in the sea continue to be discovered. For example, since the HOT program began in 1988, two novel, unexpected pathways of solar energy capture, that differ significantly from OP, 
have been reported. These new pathways of solar energy capture, aerobic anoxygenic phototrophy (Kolber and others 2000, 2001) and proteorhodopsin phototrophy (Béjà and others 2000, 2001), are most likely facultative mechanisms to supplement the energy demands and to improve the growth rates/efficiencies of otherwise obligate chemoorganoheterotrophic metabolisms in select marine bacteria and archaea. These profound discoveries could fundamentally alter our views of life in the sea, but we currently lack a quantitative understanding of the rates, controls and ecological significance of these alternate energy capture pathways in nature (Karl 2007, 2014b).

The "euphotic zone" (literally, well lit) is defined as that portion of the water column where there is sufficient light energy for net photosynthesis (Figure 2); the minimum energy flux is termed the photosynthetic compensation irradiance. At Station ALOHA, the compensation irradiance for OP is $0.054 \mathrm{~mol}$ photons $\mathrm{m}^{-2} \mathrm{~d}^{-1}$, which is equivalent to approximately $0.11 \%$ of surface 400 - to $700-\mathrm{nm}$ radiation (also termed photosynthetically available radiation [PAR]) and $1 \%$ of surface $475-\mathrm{nm}$ (blue) light based on comparisons of the light versus dark assimilation of ${ }^{14} \mathrm{C}$-labeled bicarbonate (Laws and others 2014; Figure 3 and Table 1). The corresponding compensation depth varies depending on temporal changes in water clarity, but is on average $173 \mathrm{~m}( \pm 7 \mathrm{~m})$ at Station ALOHA (Letelier and others 1996). It is not known whether aerobic anoxygenic phototrophy or proteorhodopsin-based phototrophy can occur beneath the OP compensation depth. Opposing seasonal variations in surface PAR $(\sim 50 \%$ greater in summer than in winter) and water column PAR attenuation coefficient ( $\sim 20 \%$ greater in winter than in summer) combine to yield an approximate 30 -m-depth displacement of the $1 \%$ light level from $120 \mathrm{~m}$ in summer compared to $90 \mathrm{~m}$ in winter (Letelier and others 2004; Figure 3). The top of the nitricline, defined as the shallowest depth at which the nitrate concentration gradient exceeds $2 \mu \mathrm{mol} \mathrm{m}{ }^{-4}$, also migrates upward in winter in response to the decreasing photon flux. This complex interaction of seasonal light, nutrients and phytoplankton results in a significant increase in chlorophyll $a$ concentration and deepening of the deep chlorophyll maximum layer (DCML) each summer. Letelier and others (2004) estimated that there is a net removal of at least $36 \mathrm{mmol} \mathrm{m}^{-2}$ of nitrate in the $90-200 \mathrm{~m}$ depth each summer leading to both an increase in chlorophyll a (phytoplankton biomass) and enhanced particulate organic matter export from the lower euphotic zone.
PAR continues to decrease beneath the photosynthetic compensation depth, and even at a depth of $800 \mathrm{~m}$ many marine organisms can sense and respond to this dim light. Indeed, some zooplankton and fish migrate from near the surface of the ocean to depths of about $1000 \mathrm{~m}$ on a daily basis in response to downwelling irradiance (Plueddemann and Pinkel 1989). A recent field study at Station ALOHA documented diel vertical migration of 0.5to 2-mm-sized zooplankton from depths as great as $1000 \mathrm{~m}$ during daylight hours to surface waters at night. The day-to-night differences due to migrant zooplankton were 260 and $21 \mathrm{mg}$ (dry weight) $\mathrm{m}^{-2}$ for the upper 0 - to $100-\mathrm{m}$ and $700-$ to $1000-\mathrm{m}$ depth intervals, respectively (Hannides and others 2013). Because the migrant zooplankton feed in the surface at night and respire, defecate and are subject to predation at depth, diel vertical migrations represent a net downward flux of $\mathrm{C}$ and energy at Station ALOHA (Al-Mutairi and Landry 2001; Hannides and others 2009).

In addition to solar energy, bioluminescence (biologically produced light) is ubiquitous in the marine environment. Bioluminescence is also solar powered since it derives from chemical reactions in cells and tissues that ultimately owe their existence to sunlight. Bioluminescence has a variety of functions, including quorum sensing and cell signaling, predation (offense) and predator avoidance (defense), mating and many other essential functions (Haddock and others 2010). Below about $600 \mathrm{~m}$ in the NPSG, the mean photon flux from bioluminescence exceeds downwelling sunlight (Bradner and others 1987). Bioluminescence decreases with depth reflecting a general decrease in total living biomass but is still detectable even at the greatest ocean depths (Figure 3). In addition, there is a very dim glow of Cherenkov radiation from electrons emitted in the decay of radioactive potassium $\left({ }^{40} \mathrm{~K} ; \sim 120\right.$ photons $\left.\mathrm{cm}^{-2} \mathrm{~s}^{-1}\right)$, though we have no knowledge of the potential for ${ }^{40} \mathrm{~K}$ based biological function.

\section{Diversity: The "SPICE OF LifE"}

It has been said that "variety is the spice of life, that gives it all its flavour" (William Cowper 1785, The Task). A hallmark of the NPSG is its diversity, which is due in part to its age and extensive evolutionary diversification. The diversity metrics of greatest interest to ecologists and microbial oceanographers include taxonomic/phylogenetic diversity, metabolic/trophic diversity and habitat/niche diversity. All three of these related properties contribute significantly to the spice of life and combine to 


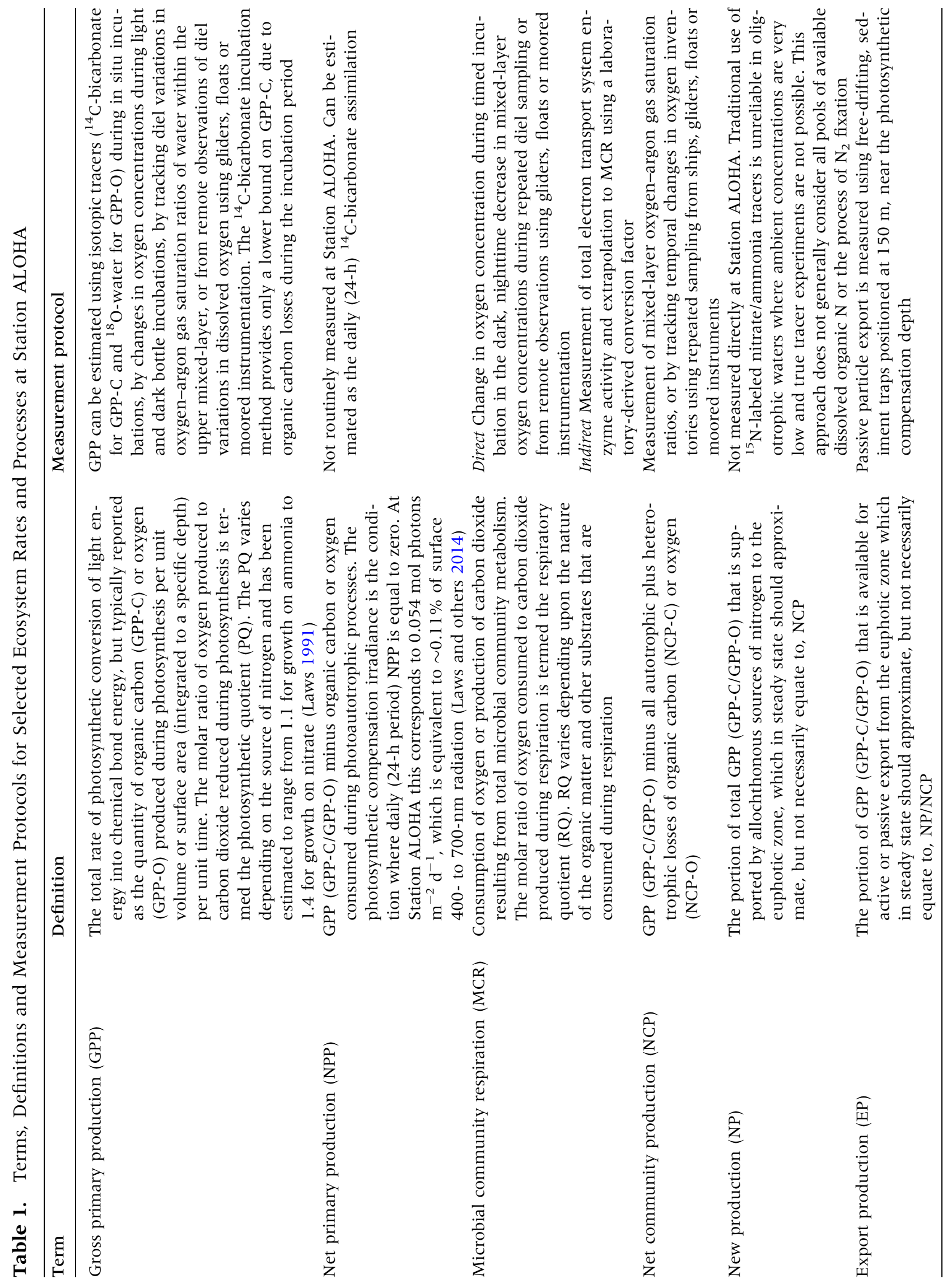


maximize the flow of energy, as well as to confer resilience to environmental variability.

Phytoplankton, broadly defined here as obligate or facultative photolithoautotrophic microorganisms (including both prokaryotic and eukaryotic forms), play a fundamental role in solar energy capture and organic matter production in the sea. Consequently, there has been great interest in assessing the phylogenetic diversity of phytoplankton in the NPSG. These research efforts can be divided into three major phases: (1) microscopic analysis of eukaryotic phytoplankton with a primary focus on the phylogeny of diatoms as an important taxonomic group in the NPSG (pre1980), (2) the discovery and exploration of picophytoplankton, small $(<2-3 \mu \mathrm{m})$ eukaryotic and prokaryotic phototrophs that fundamentally changed our view of the size structure and trophodynamics of the NPSG (1980-2000) and (3) the development and ecological application of novel DNA sequence-based methods to reveal genetic diversity and evolutionary relationships between and among the diverse phytoplankton assemblages in the NPSG.

Venrick (1971, 1982, 1990b) produced the first comprehensive analysis of eukaryotic phytoplankton diversity in the NPSG. Her pioneering research revealed the presence of high fidelity associations of diatoms and other phytoplankton species (Venrick 1971). Two distinct recurring groups of phytoplankton were observed in the upper and lower portions, respectively, of the water column separated by a region of rapid transition at approximately $100 \mathrm{~m}$ (Venrick 1982). This transition depth approximates the boundary between a light-saturated, nutrient-limited upper euphotic zone and a deeper light-limited region where nutrients begin to accumulate. Subsequent field observations during six summer cruises over a 12-year interval (1973-1985), revealed 245 and 231 unique phytoplankton species in shallow $(0-100 \mathrm{~m})$ and deep (100-200 m) portions of the water column within the Climax study region (Venrick 1990b). For each zone, 21 species accounted for about $90 \%$ of the individuals, along with a large number of rare species. The most remarkable conclusion of her study was that the rank orders of abundance of the major phytoplankton groups were similar over the greater than 1-decade observation period (equal to $>1000$ generation times for an average phytoplankton species), and that the surface populations separated by time were more similar to each other than the surface versus deep for any given year (Venrick 1990b). It was hypothesized that this low interannual variability in phytoplankton species composition must reflect a relatively stable habitat structure. Nevertheless, this relative stability in eukaryotic phytoplankton community structure was preserved despite a near doubling of the total depth-integrated chlorophyll $a$ over this same period of time (Venrick and others 1987; Figure 1B). It has been hypothesized that there may have been a systematic shift in the size structure and composition of the phytoplankton assemblages in the NPSG beginning about 1976 (Karl 1999; Karl and others 200la). Evidence was provided for a hypothesized "domain shift" from larger eukaryotic phytoplankton to dominance by smaller prokaryotic populations with altered food web structures, new and export production processes and fishery yields. It was further hypothesized that these changes may have been the result of climate variability, especially enhanced stratification of near-surface waters and decreased concentration of nutrients, both of which would select for small phytoplankton species. Observed changes in pigments, rates of primary production and nitrogen $\left(\mathrm{N}_{2}\right)$ fixation may be additional manifestations of changing ocean habitats and communities in the NPSG (Karl and others 2001a).

Our understanding of life in the sea around us is limited by the methods available or employed. In the case of Venrick's pioneering research on phytoplankton diversity and community structure, the analyses were biased toward the larger size $(>10$ $\mu \mathrm{m})$ classes of phytoplankton that were at that time thought to be the most numerous and important. The picophytoplankton "revolution" can be traced back to two independent field reports. Waterbury and others (1979) reported small $(<2 \mu \mathrm{m})$ unicellular, phycoerythrin-containing cyanobacteria in water samples collected from the Arabian Sea, Peruvian coastal waters and the Gulf Stream. These cells were similar to a coccoid cyanobacterium previously isolated (and cultured) by R. Guillard off South America that was assigned to the genus Synechococcus. This important discovery of the marine picophytoplankton concluded with the equivocation: "The ecological importance of these cyanobacteria as major primary producers in the world's oceans is still to be assessed."

Johnson and Sieburth (1979), independently working in the North Atlantic Ocean, reported the presence of a diverse assemblage of small $(<2 \mu \mathrm{m})$ chroococcoid cyanobacteria in the open sea. Transmission electron microscopy (TEM) confirmed that these cells were prokaryotic, contained photosynthetic thylakoids and, hence, were likely to be photosynthetically active under in situ conditions. The authors speculated that these pico- 
phytoplankton may be a major food source for oceanic protozooplankton and that some species might even fix $\mathrm{N}_{2}$ or perform other key ecosystem services (Johnson and Sieburth 1979). They concluded their discovery paper with a rather prescient statement: "These cells may play a significant role in oceanic primary productivity."

Shortly thereafter, a novel and abundant group of unicellular cyanobacteria containing both chlorophyll $a$ and $b$ was discovered in the North Atlantic Ocean and, subsequently, in other marine habitats (Chisholm and others 1988; Li and Wood 1988; Olson and others 1990). Although Lewin (1976) had previously reported a new division of algae, Prochlorophyta, based on his discovery of a group of symbiotic photosynthetic prokaryotes containing both chlorophyll $a$ and $b$, the discovery of free-living, planktonic Prochlorococcus was a major benchmark in the history of microbial oceanography.

Prochlorococcus is now recognized as the most abundant photoautotroph in tropical and subtropical marine environments worldwide, including Station ALOHA. This discovery and subsequent research on physiological variability (Moore and others 1998), genetic diversification (Coleman and Chisholm 2007) and niche partitioning in space and time (Bouman and others 2006; Johnson and others 2006) have led to a radically different food web and energy flow paradigm for the NPSG than were available when the HOT program began. A recent review of Prochlorococcus reveals the deeply rooted evolutionary diversity, genomic hypervariability and broad physiological capacity of what is now termed a "federation" of coexisting cells (Biller and others 2015). There is enormous cell-tocell genomic diversity (Kashtan and others 2014), and it is not entirely clear, either for Prochlorococcus or for other microorganisms, how the diversified pan-genome is sustained and whether coexisting Prochlorococcus cells occupy the same niche. Since the function of many "genes" is not yet known, a determination of the precise ecological niche is not yet possible. Even if all of the genes were perfectly annotated, their expression patterns, controls and interactions would still be required for a complete understanding of ecosystem dynamics.

$\mathrm{Li}$ and others (2013) recently employed a molecular-based method to quantify chromophytic phytoplankton (diatoms, pelagophytes, prymnesiophytes and dinoflagellates) using sequence analysis of form ID $r b c L$ genes. The observed $r b c L$ gene clone libraries revealed 4 major clades of chromophytic algae consisting of a diverse assemblage of genera with most taxa predicted from the
Climax data set, but also many novel clones. This pioneering use of a genetic biomarker for diatoms confirmed the presence of vertically segregated species assemblages (Venrick 1982, 1997) and the more recent reports of the role of prymnesiophytes and pelagophytes at Station ALOHA (Andersen and others 1996; Cortés and others 2001). The Li and others (2013) study also confirmed the year-round presence of diatoms and related chromophytic phytoplankton at Station ALOHA, despite their very low percent abundance in the total phytoplankton assemblage at Station ALOHA.

More recently, Rii (2016) examined the diversity of eukaryotic picoplankton at Station ALOHA using 18S rRNA gene fragment analysis over a 2-year period (2011-2013). The supergroup Alveolata comprised a majority $(\sim 58 \%)$ of total operational taxonomic units (OTUs) recovered from the euphotic zone $(0-175 \mathrm{~m})$, followed by stramenopiles $(\sim 10 \%)$ and Rhizaria ( 9\%). Within the Alveolata category, Syndiniales Group I and II, both known to be parasitic, were dominant (Rii 2016).

Based on these collective efforts at Station ALOHA, we now know that the picophytoplankton size fraction (approximately $0.2-2 \mu \mathrm{m}$ ), rather than the microphytoplankton size fraction $(20-200 \mu \mathrm{m})$, is the dominant component of the photoautotrophic community in terms of both numbers and biomass. However, the diversity and relative abundances of pico- and micro-sized phytoplankton at Station ALOHA can be experimentally manipulated simply by the addition of inorganic nutrients (McAndrew and others 2007). Within just a few days following modest additions of macronutrients (that is, $1-3 \mu \mathrm{M}$ nitrate, $0.1-$ $0.3 \mu \mathrm{M}$ phosphate) the phytoplankton assemblage shifts from Prochlorococcus to one dominated by large $(>10 \mu \mathrm{m})$ diatoms, with attendant changes in net community metabolism (McAndrew and others 2007). This domain-level shift, from prokaryotes to eukaryotes, supports the hypothesis of Karl and others (2001a) regarding time-dependent, climate-driven changes in NPSG plankton community structure and function. More recently, Alexander and others (2015) used eukaryotic metatranscriptome analysis to assess the phytoplankton response to nutrient loading at Station ALOHA. Replicated shipboard blooms, stimulated by nutrients, revealed that diatoms and haptophytes significantly upregulated their metabolic fingerprints relative to controls, whereas dinoflagellates showed little response (Alexander and others 2015). Furthermore, the variable transcript allocation ratio, a quantitative measure of the increase or decrease in transcript abundance, differed 
for the two taxonomic groups with diatoms exhibiting an r-trait strategy of growth consistent with their role in oligotrophic ocean blooms. Growth colimitation by nutrients, metals and vitamins appeared to ultimately control biomass production in these shipboard experiments. The magnitude of the response to nutrient perturbation and the resultant size spectrum and taxonomic structure of the phytoplankton assemblage vary seasonally, with largest changes occurring in summer (Mahaffey and others 2012). These experimental results indicate that the selection for, or against, a Prochlorococcus-dominated assemblage may be related to both the rate of nutrient delivery and the time of year, as well as to longer timescale changes in habitat structure (Karl and others 2001a).

Finally, the process of $\mathrm{N}_{2}$ fixation deserves mention because it appears to be a "keystone" biogeochemical process at Station ALOHA. Several groups of microorganisms include but are not limited to: Trichodesmium, a filamentous, free-living, non-heterocystous cyanobacterium; Cyanothece-like and Crocosphaera, small $(\sim 3 \mu \mathrm{m})$, unicellular cyanobacteria (Groups A and B, respectively; Zehr and others 2001); and Richelia intracellularis, a filamentous, heterocystous cyanobacterium that forms symbiotic associations with selected eukaryotic phytoplankton, especially diatoms. Under certain environmental conditions, these $\mathrm{N}_{2}$-fixing microorganisms can bloom, leading to significant changes in the mean states of the $\mathrm{C}$ - and $\mathrm{N}$-cycles.

\section{Primary Production and Export: The "Pulse of Life"}

The ocean's biological C pump (BCP) is an integral component of the global $\mathrm{C}$ cycle and is largely responsible for long-term sequestration of $\mathrm{CO}_{2}$ into the meso- and abyssopelagic zones (Volk and Hoffert 1985; Figure 2). The biological C pump is fueled by solar energy, through the process of photosynthesis in the euphotic zone. The primary mechanism that connects surface processes to the deep sea is the gravitational settling of organic particles and, to a lesser extent, the net downward diffusion of DOC and active vertical migrations of macrozooplankton.

Since October 1988, we have measured primary production using the traditional ${ }^{14} \mathrm{C}$ method which provides an estimate of the rate of primary production (Table 1). This estimate is certainly less than gross primary production (GPP), but greater than net primary production (NPP). For example, we know that a portion of the recently fixed ${ }^{14} \mathrm{C}$ is excreted as DOC, some of which could be immediately (that is, during the timescale of the incubation) remineralized by heterotrophic microorganisms back to ${ }^{14} \mathrm{CO}_{2}$. In addition, protistan grazing on ${ }^{14} \mathrm{C}$-labeled phytoplankton and heterotrophic bacterial cells, viral lysis, phytoplankton respiration, death and autolysis also contribute to losses of fixed, radioactive C.

The nearly three-decade-long ${ }^{14} \mathrm{C}$ data set from Station ALOHA is the most extensive of its kind for any location in the NPSG. Daily depth-integrated rates of ${ }^{14} \mathrm{C}$-based primary production at Station ALOHA range from 175 to $1100 \mathrm{mg} \mathrm{C} \mathrm{m}^{-2} \mathrm{~d}^{-1}$, with a 26 -year mean value of $525.5 \mathrm{mg} \mathrm{C} \mathrm{m}^{-2} \mathrm{~d}^{-1}$ $\left(\mathrm{SD}=135.6 \mathrm{mg} \mathrm{C} \mathrm{m}^{-2} \mathrm{~d}^{-1}\right)$, but with significant seasonal and interannual variability. The seasonal variations are due in large part to predicted/measured variations in PAR (see below and Figure 3). However, the large interannual variations for a given season cannot be attributed to PAR alone and must have additional controls, most likely variations in macronutrient fluxes, trace metals or vitamins, as well as mesoscale physical processes (see also Variability section). None of these processes are well constrained at Station ALOHA despite the enormous scientific efforts invested in the HOT, C-MORE and SCOPE programs to date.

The 26-year ${ }^{14} \mathrm{C}$-based climatology for surface ocean $(5 \mathrm{~m})$ primary production shows a maximum rate in the May-June period, consistent with increasing PAR throughout the spring-summer period (Figure 4). However, ${ }^{14} \mathrm{C}$-based primary production decreases in July, followed by an increase from August to mid-September, even though PAR continues to decrease. We interpret this to be a stratification-induced nutrient (nitrate) limitation in mid-summer, followed by a predictable late summer period of $\mathrm{N}_{2}$ fixation-based new production. The high-light, N-deficient NPSG is an ideal habitat for the proliferation of $\mathrm{N}_{2}$-fixing, phototrophic microorganisms. Although nitrate is chronically depleted, enhanced stratification during summer and higher $\mathrm{N}$ export rates (see below) combine to create a niche space for the $\mathrm{N}_{2}$-fixing microbes at Station ALOHA. While $\mathrm{N}_{2}$ fixation occurs throughout the year, average rates of $\mathrm{N}_{2}$ fixation are greatest in late summer-early fall (Böttjer and others 2016), and we conclude that it is the reason for the higher than expected (based strictly on PAR) ${ }^{14} \mathrm{C}$-based production in the HOT program climatology (Figure 4). However, sustained $\mathrm{N}_{2}$ fixation-based new production requires sources of phosphorus and iron, as well as other trace elements and organics, so eventually production is 


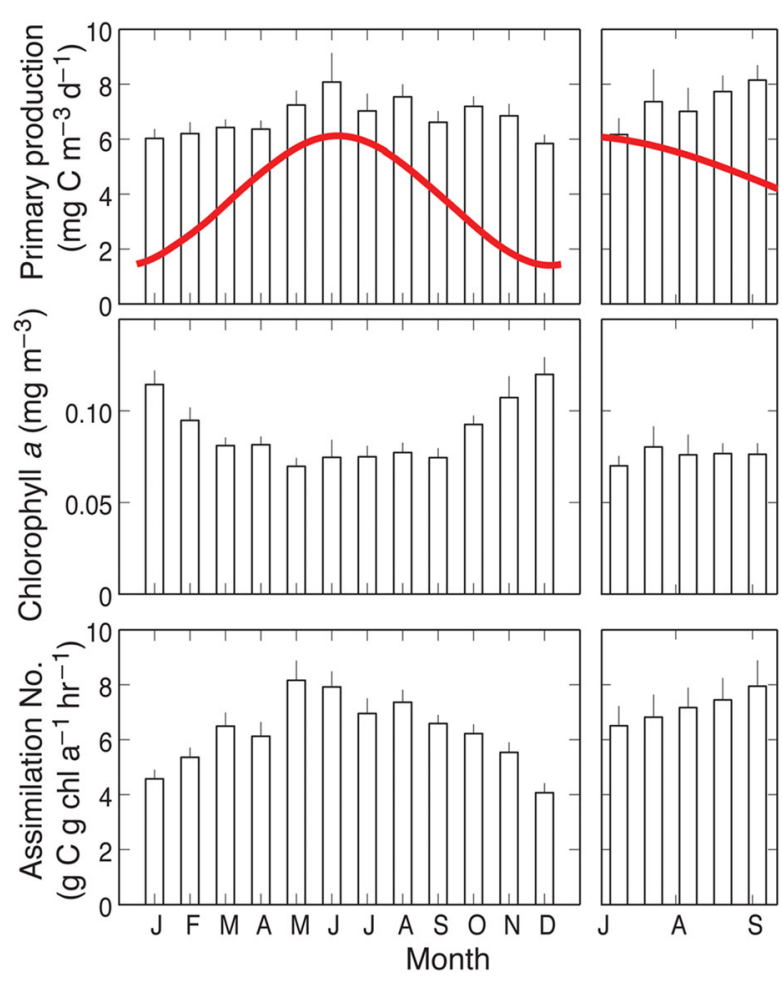

Figure 4. Primary production in the light-saturated surface ocean $(5 \mathrm{~m})$ at Station ALOHA based on 26 years of approximately monthly observations. (Top, Left) ${ }^{14} \mathrm{C}$ based primary production (shown as mean \pm 1 SD) binned by month along with clear sky, surface PAR (bold red lines $\sim 30-55$ mol quanta $\mathrm{m}^{-2} \mathrm{~d}^{-1}$; see Figure 2). (Right) Also shown is the late summer (July-September) trend, binned into 2 -week periods. (Center) Chlorophyll $a$ presented in the same format, showing a systematic, photoadaptive change in chlorophyll $a$ concentration in response to PAR. (Bottom) Assimilation number ( $\mathrm{g} \mathrm{C} \mathrm{g} \mathrm{chl}$ $a^{-1} \mathrm{~h}^{-1}$ ) in the same format, showing the increasing trend in late summer.

controlled by other factors (in addition to PAR) and primary production decreases again in late fall.

The downward flux of particulate $\mathrm{C}(\mathrm{PC})$ is one component of export production (Table 1). When measured at the base of the euphotic zone and expressed as a proportion of contemporaneous primary production, it is termed the export ratio (eratio; Baines and others 1994). Cross-ecosystem analyses from a broad range of oceanic habitats suggest that the e-ratio is a positive, nonlinear function of total euphotic zone primary production, with values ranging from less than 0.1 for oligotrophic regions to greater than 0.5 in highly productive coastal regions (Suess 1980; Pace and others 1987). Buesseler and Boyd (2009) have recently argued that the e-ratio reference point should be set at the compensation irradiance for photosynthesis (the depth where NPP is zero; see
Table 1) rather than a fixed depth, which for Station ALOHA is about $175 \mathrm{~m}$.

Since the beginning of the HOT program in 1988, we have measured the flux of PC from near the base of the euphotic zone using free-drifting particle interceptor traps (PITs, also known as sediment traps; Knauer and others 1979). PC fluxes over the 25-year observation period range from 1 to $5 \mathrm{mmol}$ $\mathrm{C} \mathrm{m}^{-2} \mathrm{~d}^{-1}$ with a mean value of $2.32 \pm 0.81 \mathrm{mmol}$ $\mathrm{C} \mathrm{m} \mathrm{m}^{-2} \mathrm{~d}^{-1}$ (Figure 5). The flux time series reveals a subdecadal variability with lower fluxes during the 1991-1996 and 2013-2014 periods, for reasons that are not well understood. Particulate N (PN) fluxes are highly correlated with PC fluxes throughout the time series with an average molar $\mathrm{C} / \mathrm{N}$ ratio of 8.0 (Figure 5). The Station ALOHA e-ratios range from 0.012 to 0.149 (mean $0.057 \pm 0.022$ ), but do not appear to be uniquely controlled by ${ }^{14} \mathrm{C}$-based primary production, as predicted by current models.

Another key variable of the BCP is the depthdependent, flux attrition commonly seen in particulate matter flux profiles due to the combined effects of disaggregation, dissolution and organic matter remineralization by microorganisms associated with the particles and particle consumption by mesopelagic zooplankton and fish (Figure 6A and B). Based on observations from the VERtical Transport and EXchange (VERTEX) program in the 1980s, Martin and others (1987) summarized their open ocean flux observations using a log-log transformation and a normalized power function in the form (Figure 6B, C):

$$
F_{z}=F_{100}(z / 100)^{-b}
$$

where $F_{z}=$ flux at a given reference depth $(z)$, $F_{100}=\log -\log$ intercept (also equivalent to the flux at $100 \mathrm{~m}), \mathrm{z}$ is depth in meters, and exponent $\mathrm{b}$ is the log-log slope of the flux versus depth relationship (also defines the flux attrition with depth). This generalized equation has been used extensively to predict PC fluxes and to constrain subeuphotic zone respiration and nutrient regeneration rates (for example, Sarmiento and Gruber 2006). Buesseler and Boyd (2009) suggested that the ratio of PC flux at the depth of the compensation irradiance to PC flux $100 \mathrm{~m}$ below that depth (termed $\mathrm{T}_{100}$ in their paper) might be more useful than the Martin equation because $T_{100}$ is a precise quantification of the BCP in the upper mesopelagic zone where the flux attrition is greatest. For Station ALOHA, the $\mathrm{T}_{100}$ reference depth range would be 175-275 m.

Flux profile data from Station ALOHA collected at reference depths of 150, 300 and $500 \mathrm{~m}$ for a 7 - 

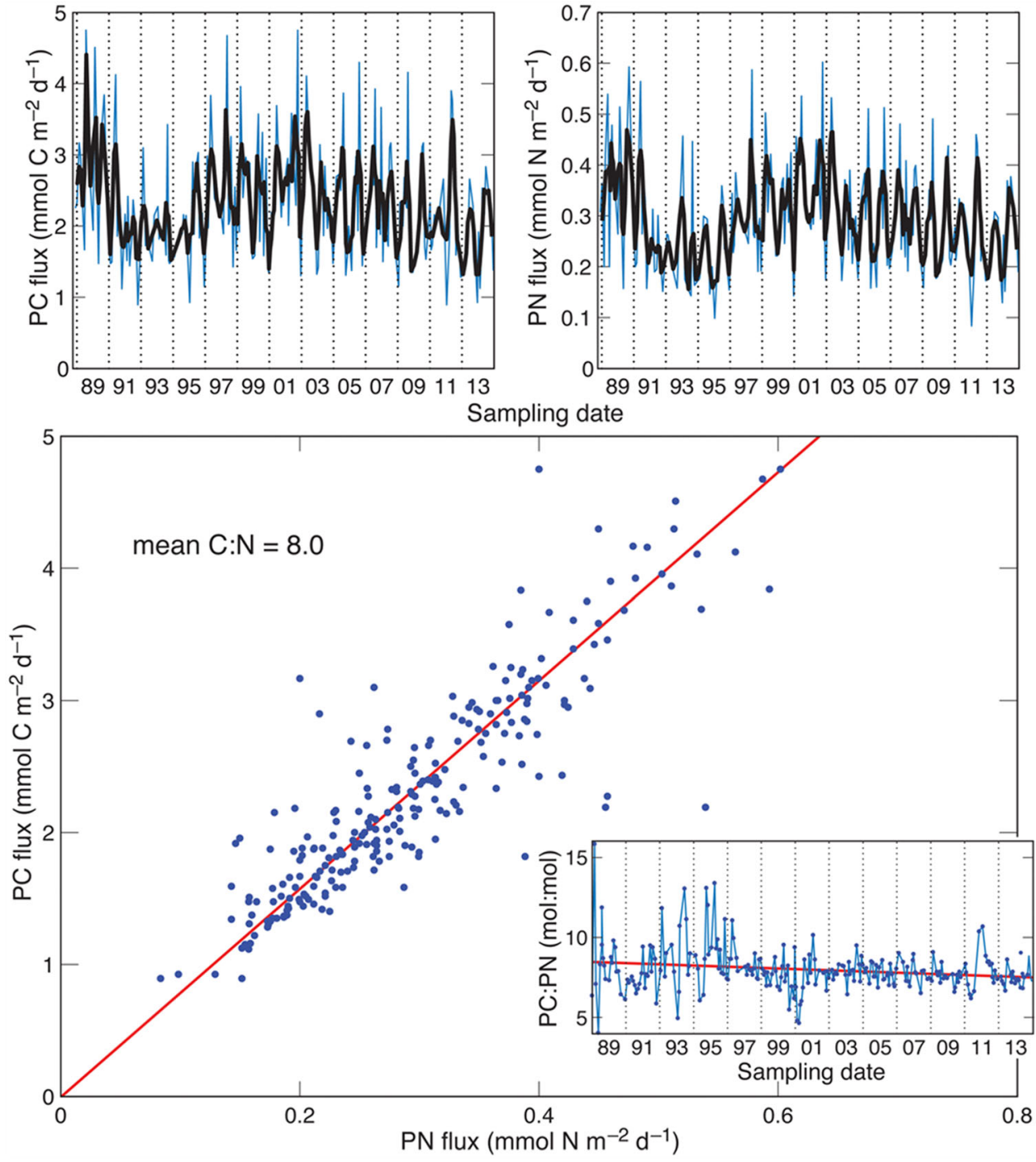

Figure 5. (Top) Particulate carbon (PC) and particulate nitrogen (PN) fluxes measured at the $150-\mathrm{m}$ reference depth at Station ALOHA during a 25-year observation period (19892014). The blue line depicts approximately monthly observations, and the dark black line is the 3-point running mean value. (Bottom) PC flux versus PN flux for the observation period with the mean C:N (8.0) value shown by the regression line. The inset shows variations in the PC/PN flux ratio over the 25 year period. year period (October 1988-November 1995; Karl and others 1996) have been modeled using the proposed normalized power function. The Station ALOHA flux attrition profile for this observation period was similar to that predicted by Martin and others (1987) and for a subsequent VERTEX data set collected in oligotrophic North Pacific waters (Knauer and others 1990; Figure 6C). However, when Station ALOHA PC flux data from the 150and 300-m reference depths are compared on a cruise-by-cruise basis, a broad range of $300 \mathrm{~m}: 150 \mathrm{~m}$ flux ratios is observed rather than convergence on a common value as predicted by the Martin and others (1987) flux attrition model (Figure 6D). Some 300-m PC fluxes exceeded the contemporaneous fluxes at $150 \mathrm{~m}$, and at other times, the 300-m PC fluxes were much lower than the model prediction (Figure 6D). A condition of equal PC fluxes at 150 and $300 \mathrm{~m}$ could be explained by very rapidly sinking particles (where microbial decomposition or removal by grazers is minimized) or by space-time decoupling of PC production and PC flux where the particles collected at 150 and $300 \mathrm{~m}$ may have different sources. In contrast, flux periods where the calculated scaling factor (the exponent b) for flux attrition with depth is greater than predicted from the Martin equation might imply either more rapid remineralization of sinking particles as a result of lower sinking rates, greater rates of dissolution and disaggregation or greater rates of microbial decomposition and removal by zooplankton and fish (processes depicted in Figure 6A). These field observations and the broad range of possible interpretations lead to the main conclusion that the structure, mechanisms and controls of the BCP at 

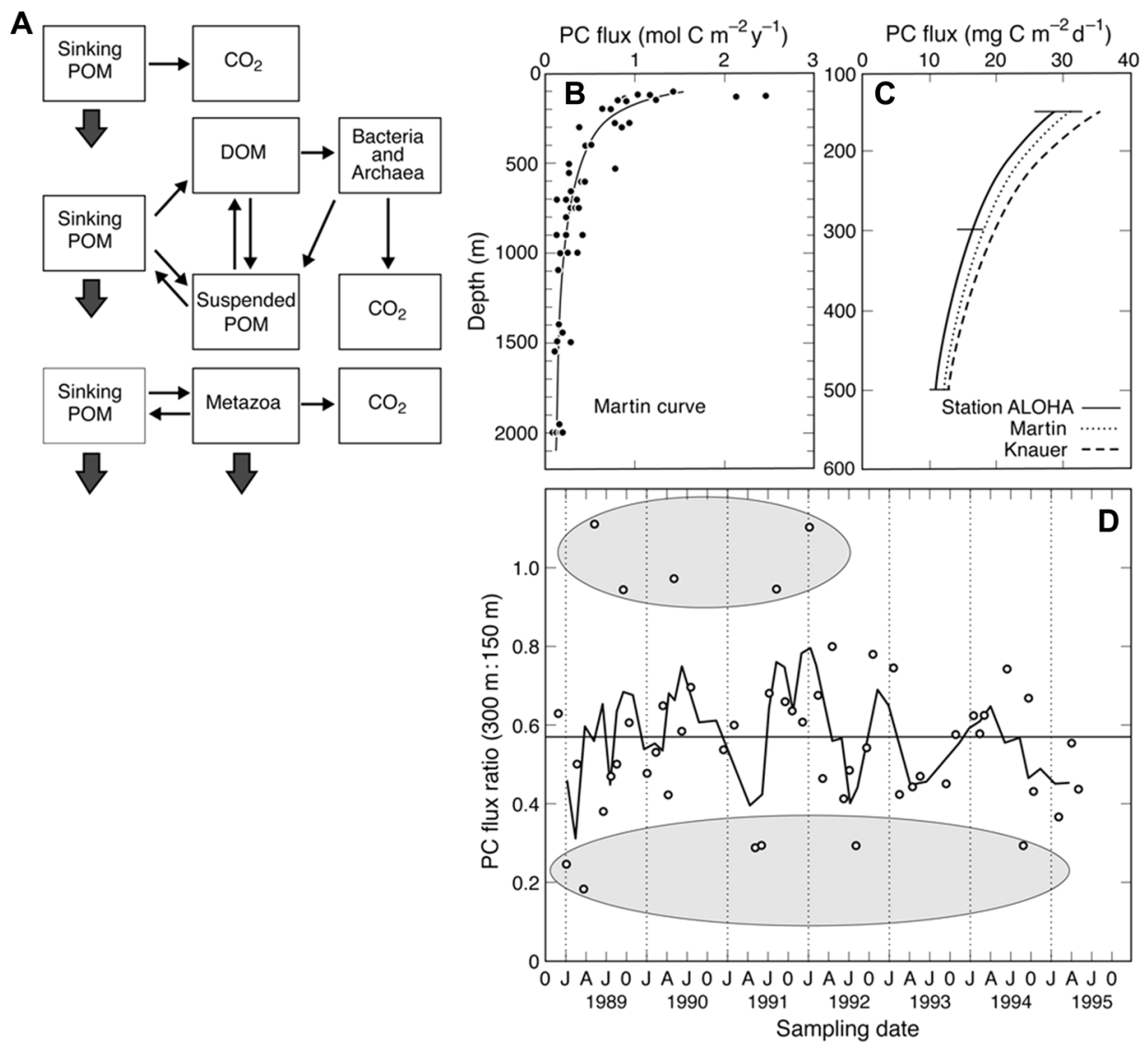

Figure 6. Key aspects of the biological carbon pump. (A) Schematic representation of the multiple possible fates of sinking particulate organic matter (POM) and transformations back to carbon dioxide $\left(\mathrm{CO}_{2}\right)$. Processes include (Top) microbial mineralization of sinking POM to carbon dioxide $\left(\mathrm{CO}_{2}\right)$, (Center) POM solubilization, hydrolysis, fragmentation, aggregation/flocculation, assimilation and microbial remineralization to $\mathrm{CO}_{2}$ and (Bottom) ingestion, egestion, molting/death and metazoan remineralization to $\mathrm{CO}_{2}$. Most likely, all of these processes contribute to the net remineralization and attrition of POM flux with depth. (B) Particulate carbon (PC) flux versus water depth for the open ocean composite data set of Martin and others (1987) and (C) for two additional NPSG data sets (VERTEX, Knauer and others 1990; Station ALOHA). Redrawn from Martin and others (1987) and Karl and others (1996). (D) Contemporaneous particulate carbon (PC) flux at $300 \mathrm{~m}$ relative to PC flux at $150 \mathrm{~m}$ during a 7-year period at Station ALOHA. The solid horizontal line at PC flux ratio $=0.57$ is the predicted flux based on the Station ALOHA curve $(\mathbf{C})$. The data points in shaded portions of the plot highlight several unusually high or low PC flux ratios (see text for more details).

Station ALOHA are not well understood. While the apparent decoupling of surface particle production and euphotic zone particle export may be the result of temporal decoupling of the two processes, it seems highly unlikely that we are undersampling any major ecosystem process related to surface ocean production and export of particles from the euphotic zone given the 25-year-long data set and approximately monthly temporal resolution. These uncertainties in the ocean's BCP remain as major enigmas with important consequences to the global $\mathrm{C}$ cycle and the long-term sequestration of $\mathrm{CO}_{2}$ in the sea.

\section{VARIABILITY: THE "UNCERTAINTY OF LIFE"}

The adage, nothing is constant but change, is an excellent description of habitat and ecosystem variability in the NPSG. Though often viewed as independent variables, there is an inextricable linkage between spatial and temporal variability in the sea (Stommel 1963; Figure 7). This complex time-space continuum defines the "uncertainty of life" for all seascapes and their inhabitants. In this section, we present three case studies of ecosystem variability at Station ALOHA. The first example explores high-frequency (hourly-daily) changes in 


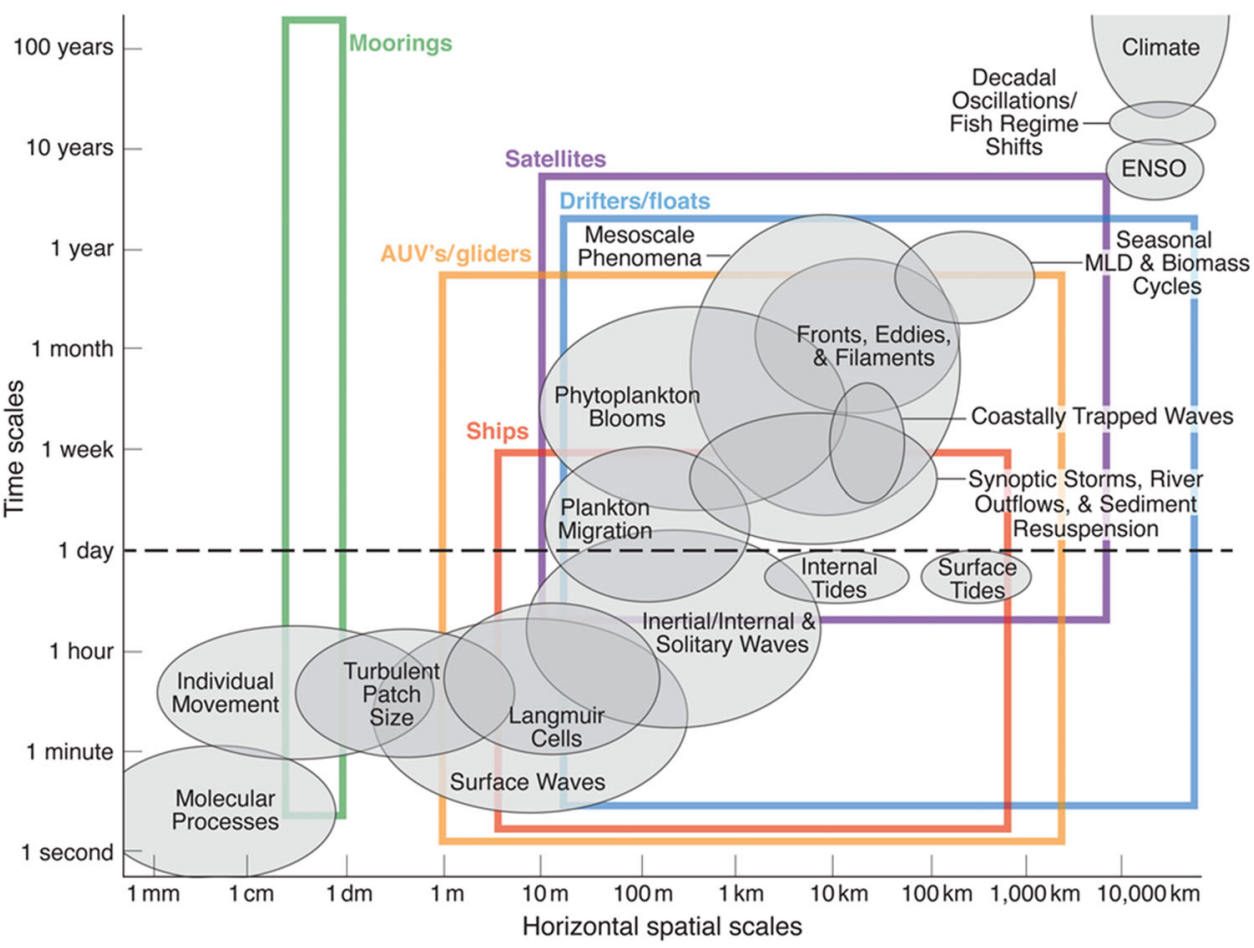

Figure 7. A "Stommel" plot showing the broad range of spatiotemporal variability in selected physical and ecosystem processes in the sea. The diel scale of variability, depicted by the horizontal dashed line, impacts all horizontal space scales. The rectangles show the approximate time and space scales for a variety of sampling/observation platforms used to study the NPSG. Adapted from Stommel (1963) and Dickey (1991). the light field that ultimately impacts primary production and all ecological processes that are tightly coupled to photosynthesis. The second case study demonstrates how mesoscale $\left(10^{\prime} \mathrm{s}\right.$ to 100 's $\mathrm{km}$ ) ocean processes can influence $\mathrm{N}_{2}$ fixation with coupled impacts on new and export production. The final example examines humaninduced environmental variability (both space and time) and potential future states of the NPSG.

\section{Diel Processes}

Within the broad ecologically relevant domain of time (Figure 7), there is probably no more significant scale than the one that occurs day-after-day, decadeafter-decade, millennium-after-millennium, namely the day-night cycle. During each 24 -h period since photosynthetic life first appeared on the planet approximately 3 billion years ago, there has been a precise diel variation in solar radiation with nearly half of each day (at the latitude of Station ALOHA) being devoid of life-supporting solar energy. So, it seems only logical that organisms, especially phototrophic microorganisms and all other populations that are tightly linked to solar energy capture via photosynthesis, have evolved metabolic strategies and behaviors to deal with the epitome of a feast-orfamine existence (for example, day versus night).

Cell division in Prochlorococcus is in synchrony with the light-dark cycle, even at ocean depths where light intensity does not permit maximum growth rates (Vaulot and others 1995). At Station ALOHA, there is a systematic progression from initial growth phase $\left(G_{1}\right)$ to DNA synthesis phase $(S)$ to late growth phase $\left(G_{2}\right)$ with cell division occurring from about sunset through midnight (Liu and others 1997). This phased cell division results in up to a twofold diel change in Prochlorococcus cell abundance, which in steady state must be balanced by corresponding losses due to grazing, viral lysis and cell death. Liu and others (1995) conducted a series of Prochlorococcus growth and mortality experiments at Station ALOHA. They concluded that mortality due to protozoan grazing accounted for between 20 and $116 \%$ of daily growth, but generally growth exceeded grazing (Liu and others 1995). More recently, Ribalet and others (2015) have documented a tightly coupled day-night synchrony between Prochlorococcus cell production and mortality rates in the NPSG. They observed a peak in mortality about $6 \mathrm{~h}$ after peak production, with essentially no mortality during daylight hours. These processes combine to result in a strong diel phasing in the flux of $\mathrm{C}$ and energy through the microbial food web via Prochlorococcus population dynamics.

Although the timing of the maximum and minimum solar energy flux at the sea surface is highly predictable, the actual solar energy flux to organisms inhabiting the euphotic zone is not. This is due to a number of stochastic properties including the pres- 
ence/absence of clouds and even cloud type, the rate and intermittency of turbulent mixing of the surface ocean (that is, the mixing rate within the so-called mixed-layer) and a variety of isopycnal vertical displacement mechanisms, including internal waves, tides and near-inertial oscillations (Letelier and others 1996; Karl and others 2002). Although we routinely measure "mixed-layer depths" at Station ALOHA, defined by one of several criteria that examine the near-surface density profiles to infer water stability, we rarely measure actual mixing rates. If the mixing rates within the mixed-layer are greater than a few meters per hour, then there may be a significant impact on estimated in vitro rates of primary production since we incubate samples at fixed water depths. Marra (1978) has shown that vertical movements, similar to those that might occur for rapid ocean mixing, can lead to significant changes in the photophysiology of phytoplankton and to variations in photosynthesis, relative to samples incubated at fixed depths. Recent measurements of upper ocean mixing at Station ALOHA in August-September 2012 using a novel method based on pigment dynamics (specifically, xanthophyll cycle pigments of chromophytic phytoplankton) estimated a mean turbulent transport velocity of $0.41( \pm 0.10) \mathrm{cm} \mathrm{s}^{-1}$ or a mixing timescale of 2$4 \mathrm{~h}$ for the $\sim 30$ - to $40-\mathrm{m}$ mixed-layer (Bidigare and others 2014). So in addition to evolutionary pressures to maximize the use of solar energy over a 24-h period, phytoplankton and other micro- and macroorganisms that are dependent on recently fixed $C$ must also be able to cope with high-frequency variations in energy flux.

Ferrón and others (2015) reported measurable diel and day-to-day variations in the dissolved oxygen to argon $\left(\mathrm{O}_{2}\right.$ :Ar) gas saturation ratios in the mixed-layer at Station ALOHA and used these data to estimate mixed-layer gross oxygen production (GPP-O; Table 1), microbial community respiration (MCR) and net community oxygen production (NCP-O; Table 1). During a 14-day observation period (March 11-25, 2014), they reported integrated mixed-layer GPP-O rates ranging from 59 to $131 \mathrm{mmol} \mathrm{O}_{2} \quad \mathrm{~m}^{-2} \mathrm{~d}^{-1}$. Furthermore, NCP-O exhibited a dynamic range from $-20 \mathrm{mmol} \mathrm{O}_{2} \mathrm{~m}^{-2}$ $\mathrm{d}^{-1}$ (net ecosystem heterotrophy) to $+42 \mathrm{mmol} \mathrm{O}_{2}$ $\mathrm{m}^{-2} \mathrm{~d}^{-1}$ (net ecosystem autotrophy), indicating large day-to-day variations for the $\mathrm{O}_{2}$ balance in the mixed-layer of Station ALOHA (Ferrón and others 2015).

In addition to turbulent mixing, other vertical displacement mechanisms may be critical for phytoplankton, especially those assemblages within the DCML where short-term vertical displacements may be greater than $60 \mathrm{~m}$ within a single inertial period ( $\sim 31 \mathrm{~h}$ at Station ALOHA). During a representative HOT cruise (HOT-83; May 1997), where a 50-m vertical displacement of the DCML was observed, the calculated daily-integrated solar radiation flux to the DCML phytoplankton on 5 consecutive days varied by nearly an order of magnitude as a result of the combined effects of clouds and inertial motions of the water column (Karl and others 2002). Other HOT cruises had smaller, or larger, day-to-day variations in solar radiation as a result of this mechanism, but neither the vertical displacement of the DCML nor cloud cover is predictable from month to month. Furthermore, because the inertial period of oscillation is longer than one day $(\sim 31 \mathrm{~h}$ at the latitude of Station ALOHA), the timing of the maximum upward and downward excursions of the DCML advances by approximately $7 \mathrm{~h}$ from one day to the next. This results in an approximately 4-day oscillation in the optimal light field for photosynthesis when the maximum upward excursion coincides with local apparent noon.

Ottesen and others (2014) reported a high-resolution (2-h intervals over a 3-day period), multispecies diel transcriptome of the microbial assemblage (0.22- to 5- $\mu \mathrm{m}$ size fraction) at Station ALOHA for samples collected in the mixed-layer in September 2011. Their analysis revealed a pattern of oscillating diel rhythms for all three domains of life (Bacteria, Eukarya and Archaea). Although the diel periodicity in Prochlorococcus transcriptomes was expected, gene expression oscillations in heterotrophic bacteria at Station ALOHA were not. Furthermore, the enigmatic temporal patterns of different heterotrophic bacterial taxa were staggered and displayed what the authors described as "waves of gene transcription" within coexisting populations of microorganisms (Ottesen and others 2014). They concluded that diel processes might control both the tempo and mode of organic matter and energy transformation in the sea. Although no mechanistic explanation for the coupled diel transcription patterns is available at the present time, these field observations emphasize the inextricable linkages between solar energy capture by phototrophs and energy dissipation by heterotrophs, consistent with a highly evolved and finely tuned microbial food web at Station ALOHA.

\section{Mesoscale Spatial Variability and the Role of Eddies}

The HOT program, by design, routinely collects data at a fixed geographical location (11-km radius 
circle centered at $22^{\circ} 45^{\prime} \mathrm{N}, 158^{\circ} \mathrm{W}$ ), whereas the ocean is in constant motion. This Eulerian sampling design cannot resolve spatial variability and assumes that horizontal changes in water column properties from hydrocast-to-hydrocast over a 3- to 4-day period of observation each month are small relative to the longer timescales of interest (seasonal to decadal). Prior to the advent of satellites, oceanographers had to rely on shipboard observations of spatial variability in oceanic processes (Hayward and McGowan 1985; Venrick 1990a), and there was no methodology available for synoptic regional or ocean basin scale assessments of sea surface properties to unambiguously resolve space and time. This all changed with NASA's launch of Seasat on June 28, 1978. For the first time, oceanographers could observe and study the "weather of the sea" (Krom and others 1993) including, but not limited to the dynamics of mesoscale $(10-100 \mathrm{~km})$ features called eddies. The key instrument, a synthetic aperture radar (SAR), provided the capability to detect and map mesoscale eddies based on precise measurements of altimetry, the distance between the satellite and the sea surface below. These topographic maps of the sea revealed a complex mosaic of eddies, some with relatively high sea surface heights (indicative of warmer water) and others with relatively low sea surface heights (indicative of cooler water). The success of Seasat inspired a generation of international satellite missions with advanced observing capabilities that have led to an improved understanding of processes in the NPSG. The previous view of the generalized NPSG basin scale topography, based on ship-based observations taken over many years (Wyrtki 1975), has been replaced with a new view, largely based on contemporary SAR imagery. Whereas the ship-based observations revealed systematic seasonal fluctuations in dynamic height associated with variations in upper ocean temperature with an annual amplitude of about 6 dyn-cm (Wyrtki 1975), the synoptic view from satellites reveals a complex, time-space continuum of mesoscale features (Figure 8). Chelton and others (2011) presented a comprehensive, global ocean analysis of eddies based on 16 years (October 1992-December 2008) of sea surface height (SSH) observations that identified 35,891 distinct features with individual lifetimes of at least 16 weeks. Eddies were ubiquitous (with notable exception of a few "eddy deserts"), but variable in terms of size, amplitude, polarity (cyclonic versus anticyclonic) and propagation dynamics (Chelton and others 2011). Mesoscale eddies create unique, but ephemeral, habitats that select for or against specific microbial taxa and metabolic functions. Foremost among the potential habitat variations is the transient change in light or nutrients due to vertical displacements in the density field, enhanced turbulent mixing or enhanced stratification of the upper water column. For example, the interactions of winds with episodic open ocean eddies can lead to intense upwelling and the formation of large blooms of diatoms in oligotrophic regions (McGillicuddy and others 1999, 2007).

Church and others (2009) conducted a 3-year study (2004-2007) of approximately monthly measurements of $\mathrm{N}_{2}$-fixing microorganism abundances, community structures and rates of $\mathrm{N}_{2}$ fixation in relation to mesoscale physical forcing at

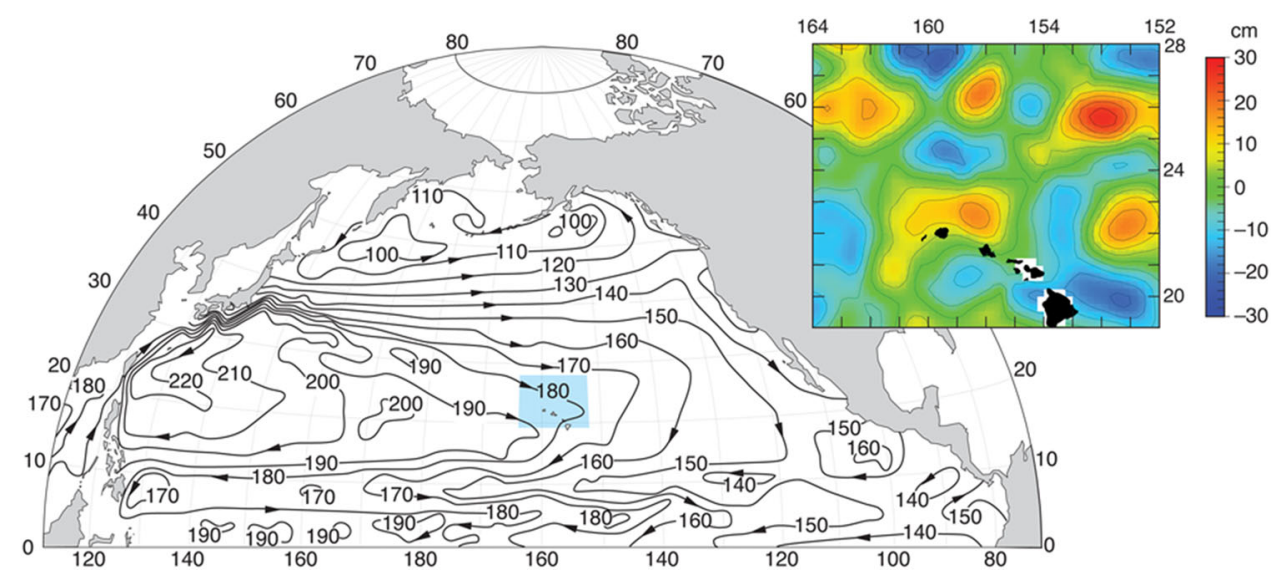

Figure 8. (Top) Dynamic topography contour map of the North Pacific surface water in dyn-cm relative to 1000 dbar based on historical shipboard observations. Arrows indicate the direction of geostrophic flow. Redrawn from Wyrtki (1975). (Inset) Satellite-based sea surface height (SSH) anomalies (cm) for the region surrounding Station ALOHA (shaded portion) in summer 2016. Data product courtesy of Colorado Center for Astrodynamics Research. 
Station ALOHA. This comprehensive analysis used a variety of data sets including ship-based HOT program observations, moored platform measurements and satellite-derived SSH anomalies measured at $1 / 3^{\circ}$ by $1 / 3^{\circ}$ resolution from the Archiving, Validation and Interpretation of Satellite Oceanography (AVISO) data archive. Temporal fluctuations in near-surface water temperature and potential density were synchronized over a broad range of SSH anomalies from -12 to $+15 \mathrm{~cm}$ (Church and others 2009). On average, a $1-\mathrm{cm}$ variation in SSH anomaly corresponded to an $\sim 2.3$ $\mathrm{m}$ vertical displacement of the position of the 24.6 potential density surface. During the 3-year period of observation, 18 significant SSH anomaly events, defined as greater than or less than 1 standard deviation of the long-term (1992-2007) mean for this region, were detected; 10 were positive SSH anomalies and 8 were negative SSH anomalies (Church and others 2009). Monthly HOT cruises coincided with 8 of the positive SSH events. Rates of $\mathrm{N}_{2}$ fixation were variable over the 3-year observation period, but were on average higher in summer than in winter. More importantly, three of the four highest mixed-layer rates of $\mathrm{N}_{2}$ fixation ( $>5 \mu \mathrm{mol} \mathrm{N} \mathrm{m} \mathrm{N}^{-3} \mathrm{~d}^{-1}$ ) occurred during cruises with strong positive $\mathrm{SSH}$ anomalies $(\geq 1 \mathrm{lcm})$, indicative of warm, anticyclonic eddies (Figure 9). The lone exception was the July $2005 \mathrm{~N}_{2}$ fixation bloom that coincided with a weaker, but still positive $(\sim 4 \mathrm{~cm})$, SSH anomaly in a decaying anticyclonic eddy (Fong and others 2008; Figure 9). Equally important, measurements of the size distribution of $\mathrm{N}_{2}$ fixation in all four of these events indicated that large cells, greater than $10 \mu \mathrm{m}$, were the most active. Quantitative polymerase chain reaction (QPCR) analyses confirmed that the larger size fraction included Trichodesmium, as well as several other heterocystous $\mathrm{N}_{2}$-fixing phylotypes (Church and others 2009). These results from Station ALOHA were consistent with a trans-Atlantic survey documenting elevated concentrations of Trichodesmium associated with positive SSH anomaly regions (Davis and McGillicuddy 2006). However, SSH anomaly alone was a poor predictor of $\mathrm{N}_{2}$ fixation rates at Station ALOHA, and moderate rates $(>2 \mu \mathrm{mol} \mathrm{N}$ $\mathrm{m}^{-3} \mathrm{~d}^{-1}$ ) of $\mathrm{N}_{2}$ fixation were often associated with cyclonic eddies. A more recent and expanded analysis (June 2005-December 2013) of the relationships between $\mathrm{N}_{2}$ fixation and mesoscale features at Station ALOHA confirmed the important role of anticyclonic eddies in regulating $\mathrm{N}_{2}$ fixation, especially during summer months (Böttjer and others 2016), yet there is still much to learn about

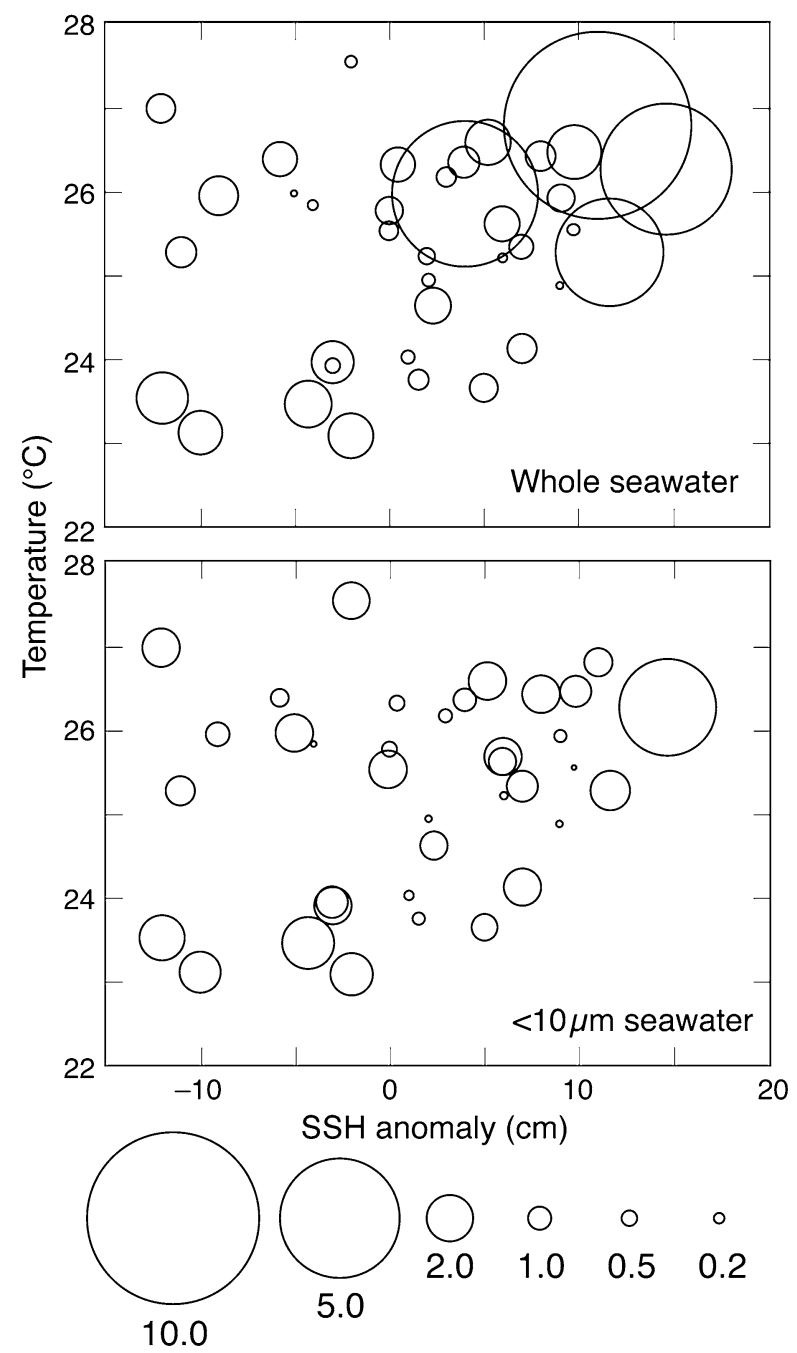

Figure 9. Bubble plots depicting relationships between near-surface ocean rates of nitrogen fixation, temperature and SSH anomalies. (Top) Whole seawater and (Bottom) $<10-\mu \mathrm{m}$ size fraction. Bubble units are $\mu \mathrm{mol} \mathrm{N}$ $\mathrm{m}^{-3} \mathrm{~d}^{-1}$. Redrawn from Church and others (2009).

the dynamics and ecological consequences of these and related mesoscale phenomena.

Nicholson and others (2008) were the first to use remotely operated Seagliders and an $\mathrm{O}_{2}$ mass balance approach to quantify NCP-O. They conducted three separate surveys from February to November 2005 of a $50 \mathrm{~km}$ by $50 \mathrm{~km}$ "bowtie"-shaped pattern centered at Station ALOHA. Dissolved $\mathrm{O}_{2}$ was measured from 0 to $1000 \mathrm{~m}$ on about 1100 profiles. This field experiment constituted the most comprehensive coverage ever achieved at Station ALOHA. In addition to obtaining the detailed seasonal progression of the subsurface $\mathrm{O}_{2}$ supersaturation feature, they also mapped several mesoscale features, four of which displayed isopycnal shoaling 
consistent with cyclonic flow. Based on these observations and a 1-dimensional model that included net turbulent diapycnal mixing and deep water entrainment, they estimated upper and lower bounds for NCP-O production of 0.9 to $1.5 \mathrm{~mol} \mathrm{O}_{2} \mathrm{~m}^{-2} \mathrm{y}^{-1}$ (Nicholson and others 2008). An important result of this impressive year-long study was the observed intermittency of NCP-O and the role of mesoscale variability in altering the rates of $\mathrm{O}_{2}$ production. During all four periods of isopycnal shoaling, biological production was elevated and the deep euphotic zone became a net autotrophic system; the opposite, net heterotrophy, was observed when isopycnals were depressed (Nicholson and others 2008).

\section{A Sea of Change}

The ocean is constantly changing on multiple time and space scales, and a proper consideration of this natural environmental variability is important for the interpretation of ecosystem dynamics at Station ALOHA and elsewhere in the world's oceans. However, recent assessments have documented an additional source of environmental variability, namely the impacts of a burgeoning human population with energy and resource demands that are beginning to change fundamental properties of the coupled ocean-land-atmosphere systems of our planet. The most recent global assessment conducted by the Intergovernmental Panel on Climate Change (IPCC) has concluded "Human influence on the climate system is clear" (Stocker and others 2013; Stocker 2015). The future ocean, circa 2100 , will be warmer, less saline, more acidic, less oxygenated and less productive than the contemporary ocean (Reid and others 2009; Gruber 2011; Pörtner and others 2014). These changes in the physical habitat will lead to altered marine ecosystems, including accelerated species extinctions, expanded oxygen minimum zones, changes in nutrient cycles and shifts or expansions in the ranges of many species (Doney and others 2012).

Station ALOHA is poised to play a major role in both the detection and interpretation of ecosystem change and in the continued refinement of our understanding of the response of the NPSG to human-induced habitat variability and change. Indeed, the 28-year (and counting) ALOHA $\mathrm{CO}_{2}$ observation program is one of the longest and most robust to track ocean acidification in the open ocean (Dore and others 2009; Church and others 2013; Bates and others 2014). A limited set of field experiments (May 2012 and September 2012) on the effects of increases in seawater $p \mathrm{CO}_{2}$ on $\mathrm{N}_{2}$ - fixing microorganisms has been conducted at Station ALOHA. No systematic, short-term (24-72 h) response of either ${ }^{14} \mathrm{C}$-based primary production or rates of $\mathrm{N}_{2}$ fixation to abrupt changes in $p \mathrm{CO}_{2}$ from control sample concentrations of about $390 \mathrm{ppm}$ to experimental concentrations in excess of $1000 \mathrm{ppm}$ was observed (Böttjer and others 2014). These results suggest that naturally occurring phytoplankton assemblages at Station ALOHA, including the very important $\mathrm{N}_{2}$-fixing species, are relatively resilient to large perturbations in $p \mathrm{CO}_{2}$. These field results are consistent with similar experiments conducted in the South Pacific Subtropical Gyre (Law and others 2012), but conflict with several laboratory studies conducted with monospecific $\mathrm{N}_{2}$-fixing cyanobacteria, including Trichodesmium, which documented enhanced rates of $\mathrm{N}_{2}$ fixation with increased $p \mathrm{CO}_{2}$ (for example, $\mathrm{Fu}$ and others 2008; Hutchins and others 2013). Recent field studies on isolated Trichodesmium colonies conducted at Station ALOHA found no consistent effect of elevated $p \mathrm{CO}_{2}$ on $\mathrm{C}$ or $\mathrm{N}_{2}$ fixation during 11 independent, short-term manipulation experiments (Gradoville and others 2014). The field results from Station ALOHA support the general null hypothesis presented several years earlier (Joint and others 2011), "major biogeochemical processes in the oceans other than calcification will not be fundamentally different under future higher $\mathrm{CO}_{2} /$ lower pH conditions." Additional laboratory and field work, designed to investigate the cumulative impacts of multiple stressors (Bopp and others 2013; Boyd and others 2015), are urgently needed to improve our understanding and predictive modeling of microbial processes in the future, changing ocean.

An additional change in NPSG habitat structure that is likely to have major impacts on microbial processes is the enhancement of upper water column stratification resulting from the combined effects of increased temperature and decreased salinity. In a series of reports beginning with Gregg and Conkright (2002), satellite-based ocean color time-series observations were used to explore the dynamics of global patterns in chlorophyll $a$ in surface ocean waters. The first analysis used data from two independent satellite missions to compare the derived chlorophyll $a$ concentrations over the approximately 2-decade-long observation period. Both seasonal and interannual changes were observed in selected regions, but the mid-ocean gyres (including the NPSG) appeared to exhibit only limited change (Gregg and Conkright 2002). In a subsequent report, Gregg and others (2003) used an improved re-analysis of the blended chlorophyll 
a data sets along with other input parameters in the vertically generalized production model (VGPM; Behrenfeld and Falkowski 1997) to examine patterns in primary production. Their results suggested that primary production had decreased globally by $6.3 \%$, from 45.3 to $42.5 \mathrm{Pg} \mathrm{C}^{-1}$, with a change of $-9.3 \%$ for the NPSG over the decade-long observation period (Gregg and others 2003). The authors hypothesized that warming of the sea surface had led to enhanced stratification and lower rates of nutrient entrainment, as predicted earlier by climate warming simulations (Sarmiento and others 1998). A follow-on study using a 6-year (19982003) Sea-viewing Wide Field-of-view Sensor (SeaWiFS) time series (Level-3, version 4, monthly, $9 \mathrm{~km}$ data) reported that the NPSG chlorophyll $a$ had decreased by $16.3 \%$ and sea surface temperature had increased by $0.31{ }^{\circ} \mathrm{C}$ per year over the observation period (Gregg and others 2005). An independent analysis reported that the most oligotrophic portions of the NPSG, defined as those regions where chlorophyll $a$ is no more than $0.07 \mathrm{mg} \mathrm{m}^{-3}$, are expanding (McClain and others 2004). These provocative conclusions (that is, lower chlorophyll $a$ concentrations, lower primary production and greater aerial extent of the most oligotrophic portion of the NPSG) were qualified with caveats concerning the relatively short duration of the observation period and the need for additional time-series data to unambiguously characterize and interpret these fundamental ecosystem changes. Nevertheless, these pioneering studies stimulated additional research to verify these trends and to predict the potential ecological and biogeochemical consequences of habitat changes in the NPSG.

Enter Polovina and others (2008), with a new analysis of a 9-year time series of SeaWiFS data (January 1998-February 2007, 9-km pixel resolution, July 2007 reprocessing by NASA, version 5.2) along with satellite-derived, $1^{\circ} \times 1^{\circ}$, monthly resolution sea surface temperature. Their analysis of these time-series observations confirmed that the most oligotrophic regions of the NPSG ( $\leq 0.07 \mathrm{mg}$ chlorophyll $a \mathrm{~m}^{-3}$ ) were expanding at an annual rate of about $2.2 \%$, and had a cumulative growth of more than 3 million $\mathrm{km}^{2}$ over the nearly onedecade period of observation (Polovina and others 2008; Figure 10). Based on predictions from a coupled climate-ocean biogeochemical model, the NPSG could expand approximately $30 \%$ by 2100 (Polovina and others 2011); however, the authors were quick to point out that their results were model-dependent. The expansion observed in the

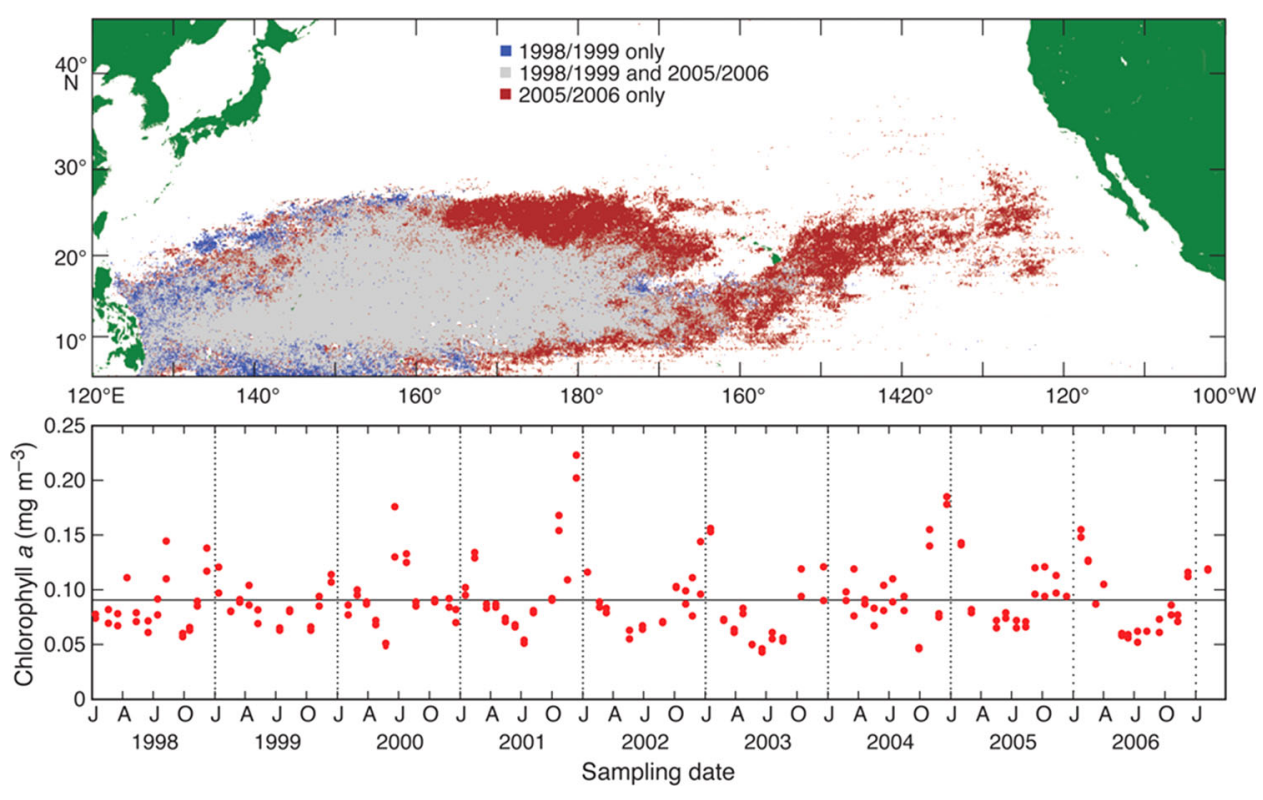

Figure 10. (Top) Changes in satellite-based chlorophyll $a$ (chl $a$ ) concentrations in the NPSG over the period 1998-2006. Colored areas indicate regions with surface chl $a \leq 0.07 \mathrm{mg} \mathrm{m}^{-3}$ for the two-month means of December 1998 and December 1999 versus December 2005 and December 2006. The blue and red regions depict those areas where low $\left(<0.07 \mathrm{mg} \mathrm{m}^{-3}\right) \mathrm{chl} a$ concentrations are observed in 1998-1999 only or 2005-2006 only, respectively; the gray regions are below the $0.07 \mathrm{mg} \mathrm{chl} a \mathrm{~m}^{-3}$ threshold for both time periods. Redrawn from Polovina and others (2008). (Bottom) Time-series observations of surface $(5 \mathrm{~m}) \mathrm{chl} a$ concentrations at Station ALOHA during this same 9-year period, showing seasonal and interannual variability around the long-term mean value of $0.089 \mathrm{mg} \mathrm{chl} a \mathrm{~m}^{-3}$. 
ocean color imagery was mostly restricted to an area between $120^{\circ} \mathrm{W}$ and the dateline and nearly encircled the region near Station ALOHA (Figure 10). The authors concluded that warming and enhanced surface ocean stratification had resulted in decreased phytoplankton biomass and productivity in the NPSG (Polovina and others 2008).

A basic premise in all of these analyses and interpretations of decade-scale changes in phytoplankton processes in the NPSG is that sea surface warming leads to enhanced stratification and a reduction in the supply of nutrients from beneath the thermocline. However, it has been shown that both strong and weak mixing of the water column at Station ALOHA can lead to enhanced primary production, but for fundamentally different reasons. The former is due to entrainment of nutrients, and the latter is due to the selection for enhancement of $\mathrm{N}_{2}$-fixing microorganisms that release the system from chronic $\mathrm{N}$ limitation. Of course, enhanced phytoplankton production under conditions of increased stratification can only be a temporary condition because other nutrients, possibly phosphate or iron, would then ultimately control primary production and export. A careful analysis of data from Station ALOHA by Dave and Lozier (2010) revealed that stratification and productivity were not strongly correlated over the observational time period (1988-2008). The authors concluded that in the absence of any strong relationship between stratification and productivity at this well-studied oligotrophic site, the observed linkages between sea surface temperature and satellite-based chlorophyll $a$, independently reported by numerous investigators, "appear to be tenuous" (Dave and Lozier 2010).

Finally, Siegel and others (2013) concluded that ocean ecosystems may be too complex to ever hope to use a single index, like satellite-based "standard chlorophyll a retrieval," as an index of phytoplankton dynamics in the surface ocean. They argued that the proper interpretation of the chlorophyll $a$ signal has at least two components: phytoplankton biomass and physiological changes due to changing mixed-layer depths (and hence, light), and for ecosystems such as the NPSG, photophysiological processes control chlorophyll a variability (Siegel and others 2013). Observational record length, time period and algorithm employed for data analysis will all impact the conclusions reached, the potential ecological implications and the projections of future ocean states in a changing world. The possibility of climate-driven expansion of the most oligotrophic regions of the NPSG is clearly in the realm of Walter Munk's definition of an inconvenient sea truth: too fundamental to be ignored, too incomplete to be understood (Munk 2009).

\section{Future Challenges and Opportunities}

The assessment of ecosystem dynamics in the NPSG must be considered a work in progress. If history is our guide, it will likely take many more decades of observations, hypothesis testing, field experimentation and modeling before a comprehensive understanding of the complex interactions and controls of key microbial and biogeochemical processes is likely to emerge. As succinctly stated by Munk and Wunsch (1982) in their crystal-ball-like prospective on "Observing the ocean in the 1990s," to understand the ocean one must observe it on a basin-wide scale with adequate time and space resolution. Chronic undersampling remains a fact of life in microbial oceanography, and even decades-long observation programs like HOT are inadequate to answer some of the most basic questions regarding microbial processes in the sea and their response to climate change. Continued access to the sea will be essential.

During the past several decades there has been remarkable progress in our understanding of NPSG ecosystem dynamics, in part, as a result of research conducted at Station ALOHA. The HOT program, founded in 1988, provided a foundation for other complementary research programs (C-MORE, SCOPE) and a locus for transdisciplinary investigations of the NPSG. However, many basic ecological questions, some presented in this review, remain and future discoveries will undoubtedly create new research opportunities and refined mechanistic models. The concept of the 'ocean microbiome' is a rapidly advancing frontier in microbial oceanography (Moran 2015; Kujawinski and others 2016). Through detailed studies of microorganisms, genes, proteins and metabolites we are beginning to learn more about functions and controls of major biogeochemical processes in the sea. Future progress in this area will require new analytical capabilities and novel approaches for the analysis and visualization of these large, complex data sets, as well as proper training of the next generation of microbial oceanographers who will need to convert these enormous streams of information into knowledge. One major challenge is the identification of 'hypothetical' genes, those open reading frames with unknown biological function. In microbial genomes and metagenomic surveys conducted to date there is always a large percentage $(30-50 \%)$ of hypothetical genes. A recent analysis of the essential gene set for the model 
cyanobacterium, Synechococcus elongates PCC7942, found that only 718 of the organism's 2723 total genes were essential for growth under laboratory conditions and of those 718 essential genes (approximately 15\%) were hypothetical (Rubin and others 2015). Even the minimal gene set for microbial life, consisting of only 473 genes (Syn 3.0), contains 149 genes with unknown biological function (Hutchison and others 2016). We will eventually need to determine the functions of all hypothetical genes (essential and non-essential) before we have the complete 'parts list' for life in the sea.

Finally, a major challenge for both science and society is the inextricable linkages between human activities and the NPSG ecosystem. Since the beginning of the Anthropocene, human-induced environmental change has begun to affect even the most remote ocean regions. In his assessment of the threat of sea level rise, Wyrtki (1990) concluded that "the effects of a doubling world population within the next 40 years will have more disastrous consequences for our environment than potential rise of sea level." The demands for energy, natural resources, food and water have irreversibly impacted natural ecosystems, including the NPSG. For example, the 'great Pacific garbage patch' is a region of the eastern North Pacific Ocean between Hawaii and California where floating debris is concentrated by gyre-scale circulation processes (Moore and others 2001; Goldstein and others 2013). Plastic, which enters the ocean via numerous transport pathways, is a major component of the garbage patch and has received a great deal of attention in recent years. Millimeter scale 'microplastics' are of greatest environmental concern because of their potential toxicity and their ability to enter the marine food web through ingestion (Law and Thompson 2014). A recent NPSG field investigation of plastic debris revealed the presence of diverse assemblages of microorganisms as well as metazoan taxa (Bryant and others 2016). The bacteria inhabiting plastic were taxonomically and functionally distinct from the surrounding picoplankton. The presence of genes encoding chemotaxis, secretion systems and cell-to-cell interactions indicated adaptations for a surface-associated lifestyle (Bryant and others 2016). High concentrations of chlorophyll $a$ and high rates of GPP-O indicated that the plastic-associated microbial assemblages were photosynthetically active, and the presence of nifH genes suggested that they may also be fixing $\mathrm{N}_{2}$ to partially satisfy their metabolic requirements. Another human impact on NPSG ecosystems is deposition of reactive nitrogen derived from anthropogenic emissions, especially from northeastern Asia (Kim and others 2014). This new and growing $\mathrm{N}$ flux pathway will lead to an imbalance in the $\mathrm{N}: \mathrm{P}$ stoichiometry of surface waters and eventually to changes in the structure and function of microbial assemblages. Over time the NPSG will become phosphorus-controlled and, probably, more oligotrophic than it is at the present time, despite the enhanced delivery of a vital nutrient. As Revelle and Suess (1957) warned, "human beings are now carrying out a large-scale geophysical experiment of a kind that could not have happened in the past, nor be reproduced in the future." There is great urgency to obtain a more comprehensive, mechanistic understanding of the NPSG, including the role of microorganisms. This is the major contemporary challenge of the sea.

\section{ACKNOWLEDGEMENTS}

We thank the co-Editors in Chief of Ecosystems, Monica Turner and Steve Carpenter, for their excellent work over the past two decades in building and sustaining this important journal and for the cordial invitation to contribute this review article. Lisa Lum, Lance Fujieki and Nancy Hulbirt provided assistance throughout this project, and countless scientists provided the important data sets and interpretations that we present and discuss herein. A huge mahalo is extended to the HOT, CMORE and SCOPE collaborators, especially the seagoing staff for their dedicated and invaluable contributions. The National Science Foundation has supported HOT from its inception in 1988 and also provided decade-long support for C-MORE (20062016). SCOPE is supported by the Simons Foundation. Additional funding has been provided by the Agouron Institute, the Gordon and Betty Moore Foundation and the Balzan Foundation.

\section{OPEN ACCESS}

This article is distributed under the terms of the Creative Commons Attribution 4.0 International License (http://creativecommons.org/licenses/by/ 4.0/), which permits unrestricted use, distribution, and reproduction in any medium, provided you give appropriate credit to the original author(s) and the source, provide a link to the Creative Commons license, and indicate if changes were made.

\section{REFERENCES}

Alexander H, Rouco M, Haley ST, Wilson ST, Karl DM, Dyhrman ST. 2015. Functional group-specific traits drive phytoplankton dynamics in the oligotrophic ocean. Proc Natl Acad Sci USA 112:E5972-9. 
Al-Mutairi H, Landry MR. 2001. Active export of carbon and nitrogen at Station ALOHA by diel migrant zooplankton. Deep-Sea Res II 48:2083-103.

Andersen RA, Bidigare RR, Keller MD, Latasa M. 1996. A comparison of HPLC pigment signatures and electron microscopic observations for oligotrophic waters of the North Atlantic and Pacific Oceans. Deep-Sea Res II 43:517-37.

Baines SB, Pace ML, Karl DM. 1994. Why does the relationship between sinking flux and planktonic primary production differ between lakes and oceans? Limnol Oceanogr 39:213-26.

Bates NR, Astor YM, Church MJ, Currie K, Dore JE, GonzalezDavila M, Lorenzoni L, Muller-Karger F, Olafsson J, SantanaCasiano JM. 2014. A time-series view of changing ocean chemistry due to ocean uptake of anthropogenic $\mathrm{CO}_{2}$ and ocean acidification. Oceanography 27:126-41.

Behrenfeld MJ, Falkowski P. 1997. Photosynthetic rates derived from satellite-based chlorophyll concentrations. Limnol Oceanogr 42:1-20.

Béjà O, Aravind L, Koonin EV, Suzuki MT, Hadd A, Nguyen LP, Jovanovich SB, Gates CM, Feldman RA, Spudich JL, Spudich EN, DeLong EF. 2000. Bacterial rhodopsin: Evidence for a new type of phototrophy in the sea. Science 289:1902-6.

Béjà O, Spudich EN, Spudich JL, Leclerc M, DeLong EF. 2001. Proteorhodopsin phototrophy in the ocean. Nature 411:786-9.

Bergh O, Borsheim KY, Bratbak G, Heldal M. 1989. High abundance of viruses found in aquatic environments. Nature 340:467-8.

Bidigare RR, Buttler FR, Christensen SJ, Barone B, Karl DM, Wilson ST. 2014. Evaluation of the utility of xanthophyll cycle pigment dynamics for assessing upper ocean mixing processes at Station ALOHA. J Plankton Res 36:1423-33.

Biller SJ, Berube PM, Lindell D, Chisholm SW. 2015. Prochlorococcus: The structure and function of collective diversity. Nat Rev Microbiol 13:13-27.

Bopp L, Resplandy L, Orr JC, Doney SC, Dunne JP, Gehlen M, Halloran P, Heinze C, Ilyina T, Séférian R, Tjiputra J, Vichi M. 2013. Multiple stressors of ocean ecosystems in the 21 st century: Projections with CMIP5 models. Biogeosciences 10:6225-45.

Böttjer D, Karl DM, Letelier RM, Viviani DA, Church MJ. 2014. Experimental assessment of diazotroph responses to elevated seawater $p \mathrm{CO}_{2}$ in the North Pacific Subtropical Gyre. Global Biogeochem Cycles 28:601-16.

Böttjer D, Dore JE, Karl DM, Letelier RM, Mahaffey C, Wilson ST, Zehr J, Church MJ. 2016. Temporal variability of dinitrogen fixation and particulate nitrogen export at Station ALOHA. Limnol Oceanogr . doi:10.1002/lno.10386.

Bouman HA, Ulloa O, Scanlan DJ, Zwirglmaier K, Li WKW, Platt T, Stuart V, Barlow R, Leth O, Clementson L, Lutz V, Fukasawa M, Watanabe S, Sathyendranath S. 2006. Oceanographic basis of the global surface distribution of Prochlorococcus ecotypes. Science 312:918-21.

Boyd PW, Lennartz ST, Glover DM, Doney SC. 2015. Biological ramifications of climate-change-mediated oceanic multistressors. Nat Clim Change 5:71-9.

Bradner H, Bartlett M, Blackinton G, Clem J, Karl D, Learned J, Lewitus A, Matsuno S, O'Connor D, Peatman W, Reichle M, Roos C, Waters J, Webster M, Yarbrough M. 1987. Bioluminescence profile in the deep Pacific Ocean. Deep-Sea Res 34:1831-40.

Bryant JA, Clemente TA, Viviani DA, Fong AA, Thomas KA, Kemp P, Karl DM, White AE, DeLong EF. 2016. Diversity and activity of communities inhabiting plastic debris in the North Pacific gyre. mSystems 1: Doi 10.1128/mSystems00024-16.

Buesseler KO, Boyd PW. 2009. Shedding light on processes that control particle export and flux attenuation in the twilight zone of the open ocean. Limnol Oceanogr 54:1210-32.

Chelton DB, Schlax MG, Samelson RM. 2011. Global observations of nonlinear mesoscale eddies. Prog Oceanogr 91:167216.

Chisholm SW, Olson RJ, Zettler ER, Goericke R, Waterbury JB, Welschmeyer NA. 1988. A novel free-living prochlorophyte abundant in the oceanic euphotic zone. Nature 334:340-3.

Chivian D, Brodie EL, Alm EJ, Culley DE, Dehal PS, DeSantis TZ, Gihring TM, Lapidus A, Lin L-H, Lowry SR, Moser DP, Richardson PM, Southam G, Wanger G, Pratt LM, Andersen GL, Hazen TC, Brockman FJ, Arkin AP, Onstott TC. 2008. Environmental genomics reveals a single-species ecosystem deep within Earth. Science 322:275-8.

Church MJ, Mahaffey C, Letelier RM, Lukas R, Zehr JP, Karl DM. 2009. Physical forcing of nitrogen fixation and diazotroph community structure in the North Pacific Subtropical Gyre. Global Biogeochem Cycles 23:GB2020, doi:10.1029/ 2008GB003418.

Church M, Lomas MW, Muller-Karger F. 2013. Sea change: Charting the course for biogeochemical ocean time-series research in a new millennium. Deep-Sea Res II 93:2-15.

Coleman ML, Chisholm SW. 2007. Code and context: Prochlorococcus as a model for cross-scale biology. Trends Microbiol 15:398-407.

Cortés MY, Bollmann J, Thierstein H. 2001. Coccolithophore ecology at the HOT station ALOHA, Hawaii. Deep-Sea Res II 48:1957-81.

Dave AC, Lozier MS. 2010. Local stratification control of marine productivity in the subtropical North Pacific. J Geophys Res 115:C12032. doi:10.1029/2010JC006507.

Davis CS, McGillicuddy DJ. 2006. Transatlantic abundance of the $\mathrm{N}_{2}$-fixing colonial cyanobacterium Trichodesmium. Science 312:1517-20.

Dickey TD. 1991. The emergence of concurrent high-resolution physical and bio-optical measurements in the upper ocean and their applications. Rev Geophys 29:383-413.

Doney SC, Ruckelshaus M, Duffy JE, Barry JP, Chan F, English CA, Galindo HM, Grebmeier JM, Hollowed AB, Knowlton N, Polovina J, Rabalais NN, Sydeman WJ, Talley LD. 2012. Climate change impacts on marine ecosystems. Annu Rev Mar Sci 4:11-37.

Dore JE, Lukas R, Sadler DW, Church MJ, Karl DM. 2009. Physical and biogeochemical modulation of ocean acidification in the central North Pacific. Proc Natl Acad Sci USA 106:12235-40.

Falkowski PG, Raven JA. 2007. Aquatic Photosynthesis. 2nd edn. Princeton and Oxford: Princeton University Press.

Ferrón S, Wilson ST, Martinez-Garcia S, Quay PD, Karl DM. 2015. Metabolic balance in the mixed layer of the oligotrophic North Pacific Ocean from diel changes in $\mathrm{O}_{2} / \mathrm{Ar}$ saturation ratios. Geophys Res Lett 42:3421-30.

Fleischmann RD, Adams MD, White O, Clayton RA, Kirkness EF, Kerlavage AR, Bult CJ, Tomb JF, Dougherty BA, Merrick JM, McKenney K, Sutton G, FitzHugh W, Fields C, Gocyne JD, Scott J, Shirley R, Liu L-I, Glodek A, Kelley JM, Weidman JF, Phillips CA, Spriggs T, Hedblom E, Cotton MD, Utterback TR, Hanna MC, Nguyen DT, Saudek DM, Brandon RC, Fine LD, Fritchman JL, Fuhrmann JL, Geoghagen NSM, Gnehm 
CL, McDonald LA, Small KV, Fraser CM, Smith HO, Venter JC. 1995. Whole-genome random sequencing and assembly of Haemophilus influenzae Rd. Science 269:496-512.

Fong AA, Karl DM, Lukas R, Letelier RM, Zehr JP, Church MJ. 2008. Nitrogen fixation in an anticyclonic eddy in the oligotrophic North Pacific Ocean. ISME J 2:663-76.

Frias-Lopez J, Shi Y, Tyson GW, Coleman ML, Schuster SC, Chisholm SW, DeLong EF. 2008. Microbial community gene expression in ocean surface waters. Proc Natl Acad Sci USA 105:3805-10.

Fu F-X, Mulholland MR, Garcia NS, Beck A, Bernhardt PW, Warner ME, Sañudo-Wilhelmy SA, Hutchins DA. 2008. Interactions between changing $p \mathrm{CO}_{2}, \mathrm{~N}_{2}$ fixation, and $\mathrm{Fe}$ limitation in the marine unicellular cyanobacterium Crocosphaera. Limnol Oceanogr 53:2472-84.

Goldstein MC, Titmus AJ, Ford M. 2013. Scales of spatial heterogeneity of plastic marine debris in the Northeast Pacific Ocean. PLOS ONE . doi:10.1371/journal/pone.0080020.

Gradoville MR, White AE, Böttjer D, Church MJ, Letelier RM. 2014. Diversity trumps acidification: Lack of evidence for carbon dioxide enhancement of Trichodesmium community nitrogen or carbon fixation at Station ALOHA. Limnol Oceanogr 59:645-59.

Gregg WW, Conkright ME. 2002. Decadal changes in global ocean chlorophyll. Geophys Res Lett 29:1730. doi:10.1029/ 2002GL014689.

Gregg WW, Conkright ME, Ginoux P, O'Reilly JE, Casey NW. 2003. Ocean primary production and climate: Global decadal changes. Geophys Res Lett 30:1809. doi:10.1029/ 2003GL016889.

Gregg WW, Casey NW, McClain CR. 2005. Recent trends in global ocean chlorophyll. Geophys Res Lett 32:L03606. doi:10. 1029/2004GL021808.

Gruber N. 2011. Warming up, turning sour, losing breath: Ocean biogeochemistry under global change. Philos Trans R Soc A 369:1980-96.

Haddock SHD, Moline MA, Case JF. 2010. Bioluminescence in the sea. Annu Rev Mar Sci 2:443-93.

Hannides CCS, Landry MR, Benitez-Nelson CR, Styles RM, Montoya JP, Karl DM. 2009. Export stoichiometry and migrant-mediated flux of phosphorus in the North Pacific Subtropical Gyre. Deep-Sea Res 56:73-88.

Hannides CCS, Popp BN, Choy A, Drazen JC. 2013. Midwater zooplankton and suspended particle dynamics in the North Pacific Subtropical Gyre: A stable isotope perspective. Limnol Oceanogr 58:1931-46.

Hayward TL, McGowan JA. 1985. Spatial patterns of chlorophyll, primary production, macrozooplankton biomass, and physical structure in the Central North Pacific Ocean. J Plankton Res 7:147-67.

Hayward TL, Venrick EL, McGowan JA. 1983. Environmental heterogeneity and plankton community structure in the central North Pacific. J Mar Res 41:711-29.

Hutchins DA, Fu F-X, Webb EA, Walworth N, Tagliabue A. 2013. Taxon-specific response of marine nitrogen fixers to elevated carbon dioxide concentration. Nat Geosci 6:790-5.

Hutchison CA, Chuang R-Y, Noskov VN, Assad-Garcia N, Deerinck TJ, Ellisman MH, Gill J, Kannan K, Karas BJ, Ma L, Pelletier JF, Qi Z-Q, Richter RA, Strychalski EA, Sun L, Suzuki Y, Tsvetanova B, Wise KS, Smith HO, Glass JI, Merryman C, Gibson DG. Venter JC. 2016. Design and synthesis of a minimal bacterial genome. Science 351:aad6253-1-aad6253-11.
Johnson PW, Sieburth JMcN. 1979. Chroococcoid cyanobacteria in the sea: A ubiquitous and diverse phototrophic biomass. Limnol Oceanogr 24:928-35.

Johnson ZI, Zinser ER, Coe A, McNulti NP, Woodward EM, Chisholm SW. 2006. Niche partitioning among Prochlorococcus ecotypes along ocean-scale environmental gradients. Science 311:1737-40.

Joint I, Doney SC, Karl DM. 2011. Will ocean acidification affect marine microbes? ISME J 5:1-7.

Karl DM. 1999. A sea of change: Biogeochemical variability in the North Pacific subtropical gyre. Ecosystems 2:181-214.

Karl DM. 2007. Microbial oceanography: Paradigms, processes and promise. Nat Rev Microbiol 5:759-69.

Karl DM. 2014a. Microbially mediated transformations of phosphorus in the sea: New views of an old cycle. Annu Rev Mar Sci 6:279-337.

Karl DM. 2014b. Solar energy capture and transformation in the sea. Elem Sci Anth 2:000021. doi:10.12952/journal.elementa. 000021.

Karl DM, Church MJ. 2014. Microbial oceanography and the Hawaii Ocean Time-series programme. Nat Rev Microbiol 12:699-713.

Karl DM, Lukas R. 1996. The Hawaii Ocean Time-series (HOT) Program: Background, rationale and field implementation. Deep-Sea Res II 43:129-56.

Karl DM, Winn CD. 1991. A sea of change: Monitoring the ocean's carbon cycle. Environ Sci Tech 25:1976-81.

Karl DM, Christian JR, Dore JE, Hebel DV, Letelier RM, Tupas LM, Winn CD. 1996. Seasonal and interannual variability in primary production and particle flux at Station ALOHA. DeepSea Res II 43:539-68.

Karl DM, Bidigare RR, Letelier RM. 2001a. Long-term changes in plankton community structure and productivity in the North Pacific Subtropical Gyre: The domain shift hypothesis. Deep-Sea Res II 48:1449-70.

Karl DM, Björkman KM, Dore JE, Fujieki L, Hebel DV, Houlihan T, Letelier RM, Tupas LM. 200lb. Ecological nitrogen-tophosphorus stoichiometry at Station ALOHA. Deep-Sea Res II 48:1529-66.

Karl DM, Bidigare RR, Letelier RM. 2002. Sustained and aperiodic variability in organic matter production and phototrophic microbial community structure in the North Pacific Subtropical Gyre. In: Thomas DR, Reynolds CS, Williams PJleB, Eds. Phytoplankton productivity and carbon assimilation in marine and freshwater ecosystems. London: Blackwell Publishers. $p$ 222-64.

Karl DM, Bidigare RR, Church MJ, Dore JE, Letelier RM, Mahaffey C, Zehr J. 2008. The nitrogen cycle in the North Pacific trades biome: An evolving paradigm. In: Bronk DA, Mulholland MR, Carpenter EJ, Capone DG, Eds. Nitrogen in the marine environment. San Diego, CA: Academic Press. p 705-69.

Kashtan N, Roggensack SE, Rodrigue S, Thompson JW, Biller SJ, Coe A, Ding H, Marttinen P, Malmstrom RR, Stocker R, Follows MJ, Stepanauskas R, Chisholm SW. 2014. Single-cell genomics reveals hundreds of coexisting subpopulations in wild Prochlorococcus. Science 344:416-20.

Kim K-N, Lee K, Gruber N, Karl DM, Bullister JL, Yang S, Kim TW. 2014. Increasing anthropogenic nitrogen in the North Pacific Ocean. Science 346:1102-6.

Kirk JTO. 2011. Light and photosynthesis in aquatic ecosystems. 3rd edn. New York: Cambridge University Press. p 649. 
Knauer GA, Martin JH, Bruland KW. 1979. Fluxes of particulate carbon, nitrogen, and phosphorus in the upper water column of the northeast Pacific. Deep-Sea Res 26:97-108.

Knauer GA, Redalje DG, Harrison WG, Karl DM. 1990. New production at the VERTEX time-series site. Deep-Sea Res 37:1121-34.

Kolber ZA, Van Dover CL, Niederman RA, Falkowski PG. 2000. Bacterial photosynthesis in surface waters of the open ocean. Nature 407:177-9.

Kolber ZA, Plumley FG, Lang AS, Beatty JT, Blankenship RE, VanDover CL, Vetriani C, Koblizek M, Rathgeber C, Falkowski PG. 2001. Contribution of aerobic photoheterotrophic bacteria to the carbon cycle of the ocean. Science 292:2492-5.

Krom MD, Brenner S, Kress N, Neori A, Gordon LI. 1993. Nutrient distributions during an annual cycle across a warmcore eddy from the E. Mediterranean Sea. Deep-Sea Res 40:805-25.

Kujawinski EB, Moran MA, Stubbins A, Fatland R. 2016. The ocean microbiome: Metabolic engine of the marine carbon cycle. Microbe 11:262-7.

Law CS, Breitbarth E, Hoffmann LJ, McGraw CM, Langlois RJ, LaRoche J, Marriner A, Safi KA. 2012. No stimulation of nitrogen fixation by non-filamentous diazotrophs under elevated $\mathrm{CO}_{2}$ in the South Pacific. Global Change Biol 18:300414.

Law KL, Thompson RC. 2014. Microplastics in the seas. Science 345:144-5.

Laws EA. 1991. Photosynthetic quotients, new production and net community production in the open ocean. Deep-Sea Res 38:143-67.

Laws EA, Letelier RM, Karl DM. 2014. Estimating the compensation irradiance in the ocean: The importance of accounting for non-photosynthetic uptake of inorganic carbon. Deep-Sea Res 93:35-40.

Letelier RM, Dore JE, Winn CD, Karl DM. 1996. Seasonal and interannual variations in photosynthetic carbon assimilation at Station ALOHA. Deep-Sea Res II 43:467-90.

Letelier RM, Karl DM, Abbott MR, Bidigare RR. 2004. Light driven seasonal patterns of chlorophyll and nitrate in the lower euphotic zone of the North Pacific Subtropical Gyre. Limnol Oceanogr 49:508-19.

Lewin RA. 1976. Prochlorophyta as a proposed new division of algae. Nature 261:697-8.

Li B, Karl DM, Letelier RM, Bidigare RR, Church MJ. 2013. Variability of chromophytic phytoplankton in the North Pacific Subtropical Gyre. Deep-Sea Res II 93:84-95.

Li WKW, Wood M. 1988. Vertical distribution of North Atlantic ultraphytoplankton: Analysis by flow cytometry and epifluorescence microscopy. Deep-Sea Res 35:1615-38.

Lin L-H, Wang P-L, Rumble D, Lippmann-Pipke J, Boice E, Pratt LM, Lollar BS, Brodie EL, Hazen TC, Andersen GL, DeSantis TZ, Moser DP, Kershaw D, Onstott TC. 2006. Long-term sustainability of a high-energy, low-diversity crustal biome. Science 314:479-82.

Liu H, Campbell L, Landry MR. 1995. Growth and mortality rates of Prochlorococcus and Synechococcus measured with a selective inhibitor technique. Mar Ecol Prog Ser 116:277-87.

Liu H, Nolla HA, Campbell L. 1997. Prochlorococcus growth rate and contribution to primary production in the equatorial and subtropical North Pacific Ocean. Aquat Microb Ecol $12: 39-47$.
Mahaffey C, Björkman KM, Karl DM. 2012. Phytoplankton response to deep seawater nutrient addition in the North Pacific Subtropical Gyre. Mar Ecol Prog Ser 460:13-34.

Marra J. 1978. Phytoplankton photosynthetic response to vertical movement in a mixed layer. Mar Biol 46:203-8.

Martin JH, Knauer GA, Karl DM, Broenkow WW. 1987. VERTEX: Carbon cycling in the Northeast Pacific. Deep-Sea Res 34:267-85

McAndrew PM, Björkman KM, Church MJ, Morris PJ, Jachowski N, Williams PJleB, Karl DM. 2007. Metabolic response of oligotrophic plankton communities to deep water nutrient enrichment. Mar Ecol Prog Ser 332:63-75.

McClain CR, Signorini SR, Christian JR. 2004. Subtropical gyre variability observed by ocean-color satellites. Deep-Sea Res II $51: 281-301$.

McGillicuddy DJ Jr, Johnson R, Siegel DA, Michaels AF, Bates NR, Knap AH. 1999. Mesoscale variations of biogeochemical properties in the Sargasso Sea. J Geophys Res 104:13381-94.

McGillicuddy DJ, Anderson LA, Bates NR, Bibby T, Buesseler KO, Carlson CA, Davis CS, Ewart C, Falkowski PG, Goldthwait SA, Hansell DA, Jenkins WJ, Johnson R, Kosnyrev VK, Ledwell JR, Li QP, Siegel DA, Steinberg DK. 2007. Eddy/wind interactions stimulate extraordinary mid-ocean plankton blooms. Science 316:1021-6.

Moore CJ, Moore SL, Leecaster MK, Weisberg SB. 2001. A comparison of plastic and plankton in the North Pacific central gyre. Mar Poll Bull 42:1297-300.

Moore LR, Rocap G, Chisholm SW. 1998. Physiology and molecular phylogeny of coexisting Prochlorococcus ecotypes. Nature 393:464-7.

Moran MA. 2015. The global ocean microbiome. Science . doi:10.1126/science.aac8455.

Munk W. 2009. An inconvenient sea truth: Spread, steepness, and skewness of surface slopes. Annu Rev Mar Sci 1:377-415.

Munk W, Wunsch C. 1982. Observing the ocean in the 1990s. Philos Trans R Soc Lond A 307:439-64.

Nicholson D, Emerson S, Eriksen CC. 2008. Net community production in the deep euphotic zone of the subtropical North Pacific gyre from glider surveys. Limnol Oceanogr 53:222636.

Olson RJ, Chisholm SW, Zettler ER, Altabet MA, Dusenberry JA. 1990. Spatial and temporal distributions of prochlorophyte picoplankton in the North Atlantic Ocean. Deep-Sea Res 37:1033-51.

Ottesen EA, Young CR, Gifford SM, Eppley JM, Marin RIII, Schuster SC, Scholin CA, DeLong EF. 2014. Multispecies diel transcriptional oscillations in open ocean heterotrophic bacterial assemblages. Science 345:207-12.

Pace ML, Knauer GA, Karl DM, Martin JH. 1987. Primary production, new production and vertical flux in the eastern Pacific Ocean. Nature 325:803-4.

Plueddemann AJ, Pinkel R. 1989. Characterization of the patterns of diel migration using a Doppler sonar. Deep-Sea Res 36:509-30.

Polovina JJ, Howell EA, Abecassis M. 2008. Ocean's least productive waters are expanding. Geophys Res Lett 35:L03618. doi:10.1029/2007GL031745.

Polovina JJ, Dunne JP, Woodworth PA, Howell EA. 2011. Projected expansion of the subtropical biome and contraction of the temperate and equatorial upwelling biomes in the North Pacific under global warming. ICES J Mar Sci 68:986-95. 
Pörtner H-O, Karl DM, Boyd PW, Cheung WL, Lluch-Cota SE, Nojiri Y, Schmidt DN, Zavialov PO. 2014. Ocean systems. In: Field CB, Barros VR, Dokken DJ, Mach KJ, Mastrandrea MD, Bilir TE, Chatterjee M, Ebi KL, Estrada YO, Genova RC, Girma B, Kissel ES, Levy AN, MacCracken S, Mastrandrea PR, White, LL, Editors. Climate Change 2014: Impacts, Adaptation, and Vulnerability. Part A: Global and Sectoral Aspects. Contribution of Working Group II to the Fifth Assessment Report of the Intergovernmental Panel on Climate Change. Cambridge University Press: Cambridge, p. 411-84.

Reid PC, Fischer AC, Lewis-Brown E, Meredith MP, Sparrow M, Andersson AJ, Antia A, Bates NR, Bathmann U, Beaugrand G, Brix H, Dye S, Edwards M, Furevik T, Gangstø R, Hátún H, Hopcroft RR, Kendall M, Kasten S, Keeling R, Le Quéré C, Mackenzie FT, Malin G, Mauritzen C, Olafsson J, Paull C, Rignot ED, Shimada K, Vogt M, Wallace C, Wang Z, Washington R. 2009. Impacts of the oceans on climate change. Adv Mar Biol 56:1-150.

Revelle R, Suess HE. 1957. Carbon dioxide exchange between atmosphere and ocean and the question of an increase of atmospheric $\mathrm{CO}_{2}$ during the past decade. Tellus 9:18-27.

Ribalet F, Swalwell J, Clayton S, Jiménez V, Sudek S, Lin Y, Johnson ZI, Worden AZ, Armbrust EV. 2015. Light-driven synchrony of Prochlorococcus growth and mortality in the subtropical Pacific gyre. Proc Natl Acad Sci USA 112:8008-12.

Rii YM. 2016. Ecology of photosynthetic picoeukaryotes in the oligotrophic ocean: Diversity, activity, and dynamics. Ph.D. Dissertation.

Rubin BE, Wetmore KM, Price MN, Diamond S, Shultzaberger RK, Lowe LC, Curtin G, Arkin AP, Deutschbauer A, Golden SS. 2015. The essential gene set of a photosynthetic organism. Proc Natl Acad Sci USA . doi:10.1073/pnas.1519220112.

Sarmiento JL, Gruber N. 2006. Ocean biogeochemical dynamics. Princeton University Press: New Jersey. 503 pages.

Sarmiento JL, Hughes TMC, Stouffer RJ, Manabe S. 1998. Simulated response of the ocean carbon cycle to anthropogenic climate warming. Nature 393:245-9.

Siegel DA, Behrenfeld MJ, Maritorena S, McClain CR, Antoine D, Bailey SW, Bontempi PS, Boss ES, Dierssen HM, Doney SC, Eplee RE, Evans RH, Feldman GC, Fields E, Franz BA, Kuring NA, Mengelt C, Nelson NB, Patt FS, Robinson WD, Sarmiento JL, Swan CM, Werdell PJ, Westberry TK, Wilding JG, Yoder JA. 2013. Regional to global assessments of phytoplankton dynamics from the SeaWiFS mission. Remote Sens Environ 135:77-91

Stocker TF. 2015. The silent services of the world ocean. Science 350:764-5.

Stocker TF, and others, Editors. 2013. Intergovernmental Panel on Climate Change, Summary for policymakers. In: Climate change 2013: The physical science basis. Contribution of Working Group I to the Fifth Assessment Report of the Intergovernmental Panel on Climate Change. Cambridge Univ Press: Cambridge. p. 1-30.
Stommel H. 1963. Varieties of oceanographic experience. Science 139:572-6.

Suess E. 1980. Particulate organic carbon flux in the oceanssurface productivity and oxygen utilization. Nature 288:2603.

Torrella F, Morita RY. 1979. Evidence by electron micrographs for a high incidence of bacteriophage particles in the waters of Yaquina Bay, Oregon: ecological and taxonomical implications. Appl Environ Microbiol 37:774-8.

Vaulot D, Marie D, Olson RJ, Chisholm SW. 1995. Growth of Prochlorococcus, a photosynthetic prokaryote, in the equatorial Pacific Ocean. Science 268:1480-2.

Venrick EL. 1971. Recurrent groups of diatom species in the North Pacific. Ecology 52:614-25.

Venrick EL. 1982. Phytoplankton in an oligotrophic ocean: Observations and questions. Ecol Monogr 52:129-54.

Venrick EL. 1990a. Mesoscale patterns of chlorophyll $a$ in the Central North Pacific. Deep-Sea Res 37:1017-31.

Venrick EL. 1990b. Phytoplankton in an oligotrophic ocean: Species structure and interannual variability. Ecology 71:1547-63.

Venrick EL. 1997. Comparison of the phytoplankton species composition and structure in the Climax area (1973-1985) with that of station ALOHA (1994). Limnol Oceanogr 42:1643-8.

Venrick EL, McGowan JA, Cayan DR, Hayward TL. 1987. Climate and chlorophyll $a$ : Long-term trends in the central North Pacific Ocean. Science 238:70-2.

Venter JC, Remington K, Heidelberg JF, Halpern AL, Rusch D, Eisen JA, Wu DY, Paulsen I, Nelson KE, Nelson W, Fouts DE, Levy S, Knap AH, Lomas MW, Nealson K, White O, Peterson J, Hoffman J, Parsons R, Baden-Tillson H, Pfannkoch C, Rogers YH, Smith OH. 2004. Environmental genome shotgun sequencing of the Sargasso Sea. Science 304:66-74.

Volk T, Hoffert MI. 1985. Ocean carbon pumps: Analysis of relative strengths and efficiencies in ocean-driven atmospheric $\mathrm{CO}_{2}$ changes. In: Sundquist ET, Broecker WS, editors. The carbon cycle and atmospheric $\mathrm{CO}_{2}$ : Natural variations Archaean to present. American Geophysical Union: Washington, D.C. p. 99-110.

Waterbury JB, Watson SW, Guillard RRL, Brand LE. 1979. Widespread occurrence of a unicellular, marine, planktonic, cyanobacterium. Nature 277:293-4.

Wyrtki K. 1975. Fluctuation of the dynamic topography in the Pacific Ocean. J Phys Oceanogr 5:450-9.

Wyrtki K. 1990. Sea level rise: The facts and the future. Pac Sci 44:1-16.

Zehr JP, Turner PJ, Omoregie E, Hansen A, Steward GF, Waterbury JB, Montoya JP, Karl DM. 2001. Unicellular cyanobacteria fix $\mathrm{N}_{2}$ in the subtropical North Pacific Ocean. Nature 412:635-8. 